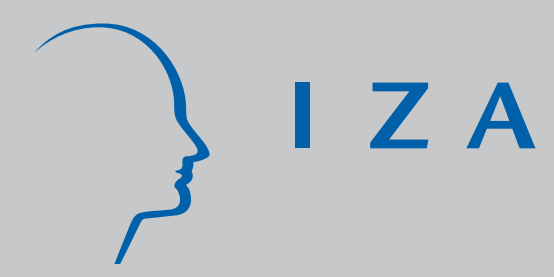

IZA DP No. 2316

How Destructive Is Creative Destruction?

The Costs of Worker Displacement

Kristiina Huttunen

Jarle Møen

Kjell G. Salvanes

September 2006 


\title{
How Destructive Is Creative Destruction? The Costs of Worker Displacement
}

\author{
Kristiina Huttunen \\ Uppsala University \\ Jarle Møen \\ Norwegian School of Economics \\ and Statistics Norway \\ Kjell G. Salvanes \\ Norwegian School of Economics, \\ Statistics Norway and IZA Bonn
}

Discussion Paper No. 2316

September 2006

\author{
IZA \\ P.O. Box 7240 \\ 53072 Bonn \\ Germany \\ Phone: +49-228-3894-0 \\ Fax: +49-228-3894-180 \\ E-mail: iza@iza.org
}

Any opinions expressed here are those of the author(s) and not those of the institute. Research disseminated by IZA may include views on policy, but the institute itself takes no institutional policy positions.

The Institute for the Study of Labor (IZA) in Bonn is a local and virtual international research center and a place of communication between science, politics and business. IZA is an independent nonprofit company supported by Deutsche Post World Net. The center is associated with the University of Bonn and offers a stimulating research environment through its research networks, research support, and visitors and doctoral programs. IZA engages in (i) original and internationally competitive research in all fields of labor economics, (ii) development of policy concepts, and (iii) dissemination of research results and concepts to the interested public.

IZA Discussion Papers often represent preliminary work and are circulated to encourage discussion. Citation of such a paper should account for its provisional character. A revised version may be available directly from the author. 
IZA Discussion Paper No. 2316

September 2006

\section{ABSTRACT}

\section{How Destructive Is Creative Destruction? The Costs of Worker Displacement ${ }^{*}$}

We analyze short and long-term effects of worker displacement. Our focus is on prime-age male workers displaced from Norwegian manufacturing plants. We find that displacement increases the probability of exiting the labor force by about 5 percentage points. This indicates that studies using data that do not incorporate workers leaving the labor force, may strongly underestimate the costs of displacement. The most productive workers are recalled, transferred to a different plant within the firm, or they move to the private sector. The least productive re-employed workers move to the public sector. Generally, the earnings effects are weak. When controlling for worker fixed effects, we find that all workers suffer some short-term losses, even those re-employed within the same firm, but the only workers that seem to suffer a permanent earnings loss are the few who move to the public sector.

JEL Classification: J63, J65

Keywords: displaced workers, permanent job-loss, reemployment, matched employeremployee data, Norway

Corresponding author:

Kjell G. Salvanes

Department of Economics

Norwegian School of Economics and Business Administration

Helleveien 30

N-5045 Bergen

Norway

Email: kjell.salvanes@nhh.no

\footnotetext{
* We would like to thank the participants at several conferences and seminars. The project has received financial support from the Research Council of Norway, the Finnish Cultural Foundation, and the Yrjö Jahnsson Foundation.
} 


\section{Introduction}

In competitive markets there is continuous entry and exit of firms. Productive and innovative firms expand and less productive firms downsize. This is the process of creative destruction, widely thought to be the most important source of long-term economic growth. However, such reallocation is not frictionless, and the burden of restructuring is not equally distributed across workers.

Research suggests that the effects of being displaced are quite detrimental. The majority of US studies analyzing the costs of involuntary job loss indicate that earnings and employment losses of displaced workers are large and persistent. ${ }^{1}$ For high-tenured workers, earnings losses are estimated to be up to 25 percent, four years after losing their jobs. Studies of displaced workers in European countries are fewer and the results less clear. The general picture for Europe is that while earnings losses are smaller, time out from employment is longer than in the USA. The results depend to a great extent on the groups of workers who are included in the data, how displaced workers are defined and what type of workers are used as a comparison group. One particular shortcoming of the previous studies is that they use a sample of workers within the labor force to measure earnings loss and employment. Obviously this may underestimate the true costs of displacement, as displacement might influence the probability of leaving the labor force permanently.

This paper makes two main contributions. First, we explicitly analyze the probability that workers leave the labor force permanently after being displaced. This is possible because we have matched employer-employee data for the entire Norwegian population of workers and plants. Such census data have an advantage over more commonly used individual or household level survey data by making it possible to identify workers outside the labor force. Second, we extend a standard analysis of the average effect of displacement for workers staying in the labor force by conditioning in a detailed manner on where the displaced workers find new employment. To our knowledge, this paper is the first to assess the costs of displacement conditened on workers' sorting. Exploring in what firms and sectors displaced workers end up, illuminates the role of displacement in industry restructuring. This approach is also informative about who bears the burden of restructuring. To mitigate endogeneity problems, we use the standard procedure in the literature and define displaced workers as those displaced from

\footnotetext{
${ }^{1}$ See surveys by Hamermesh (1987), Fallick (1996) and Kletzer (1998).
} 
exiting plants and plants downsizing 30 percent or more. We have very rich data both on both worker and firm characteristics. We exploit these variables to establish narrow comparison groups within a regression framework. The long panel available also allows for worker fixed effects. Our sample consists of prime age male workers that were full time employed in manufacturing in May 1991. Our treatment group is those workers displaced from their job between May 1991 and May 1992. Hence, 1991 is the base year of our analysis, and we follow the workers three years before this base year and seven years after.

Our descriptive analysis demonstrates the fact that the employment effects of displacement are far more pronounced than the earnings effects both in the short and long run. We find that displacement increases the probability of leaving the labor force, especially in the long run. About 13 percent of the displaced workers leave the labor force within seven years, while 8 percent of the nondisplaced workers leave the labor force within the same time span, a difference of about 5 percentage points. Transfers to other plants within multiplant firms upon displacement are quite common. In the short run, 20 percent of the displaced workers find a new job within the firm. Recall to downsizing plants is not unusual either. As many as 9 percent of workers displaced from downsizing plants are back at the plant seven years later. The relative share of employed workers changing industry is far higher among displaced workers than among the nondisplaced workers. This suggests that displacement is a powerful vehicle for industry restructuring.

The average effect of displacement on earnings is fairly small. We demonstrate, however, that the effect is heterogeneous. It depends both on where the workers find new employment, and in particular on how the treatment and control groups are defined. Including all workers in the analysis, we find that the displaced workers' earnings are on average reduced by 11 percent in the second year after the job loss. The effect decreases slowly and is 4 percent in the seventh post-displacement year. Limiting both the control and treatment groups to workers in the labor force, the average effect is significantly smaller, around 4 percent in the short run, and zero after seven years. This implies that the effect of displacement may be severely underest!imated if the data used do not include workers leaving the labor force. Exploring worker heterogeneity, we find that the most productive workers stay within the firm they were displaced from or transfer to the private sector. The least productive workers transfer to the public sector. When controlling for worker fixed effects, we find that all workers 
suffer some short-term losses, even those re-employed within the same firm. The only workers that seem to suffer a permanent earnings loss, however, are those who move to the public sector. This loss can be intepreted as a compensating differential associated with job amenities in the public sector.

The rest of this paper is organized as follows: Section 2 discusses the previous literature. Section 3 describes the data, gives details on the sample construction and explains the definition of key variables. Section 4 describes relevant labor market institutions in Norway. Section 5 presents descriptive evidence. Section 6 provides the results from the regression analysis, and Section 7 concludes the paper.

\section{Previous Literature}

The costs of displacement have been studied intensively for the last 25 years. Until recently, most of these studies analyzed displacement only in the US labor market. The results indicate substantial negative earnings effects both in the short and in the long run. The earnings loss starts at least three years before displacement and persists for many years. The approach of using comparison groups for measuring the effect of displacement, i.e. measuring the earnings change for displaced workers relative to a control group that is not displaced, was initiated in the early 1990s with papers by Ruhm (1991a and b) and Jacobson et al. (1993). In their seminal work, Jacobson et al. (1993) define workers as displaced if they leave a firm that experienced significant downsizing. They use as a comparison group the workers who do not leave their firms. They find that displaced workers suffer large and long-lasting earnings reductions after displacement. Five years after displacement, average quarterly earnings losses were 25 percent. Stevens (1997) examines long-term effects of job displacement on earnings. She finds that the effects of displacement are quite persistent, with earnings and wages remaining approximately 9 percent below their expected levels six years or more after displacement. Much of this persistence can be explained by additional job losses in the years following displacement. Workers who avoid additional displacements have earnings and wage losses around 1-2 percent six or more years after the initial displacement. Several other studies have confirmed the big earnings losses of displaced workers in the US (see e.g. Kletzer and Fairlie, 2003).

In contrast to the large supply of US studies, studies using European data on 
the costs of job displacement have been scarce. As in the US studies, the main focus has been on earnings losses following displacement. The results of these studies are difficult to summarize, as they appear to provide rather mixed results. On average smaller short-term and long-term earnings losses have been reported in Europe than in the USA ${ }^{2}$.

Most data sets used in displacement studies cover only workers who remain in the labor force ${ }^{3}$. This will tend to underestimate the displacement costs, since an obvious consequence of job displacement is that workers might permanently withdraw from the labor force. Chan and Stevens (2001) examine the employment patterns of older workers $(50+)$ after job loss, using US data. They find that a job loss results in large and lasting effects on future employment probabilities. Four years after a job loss, at age $55+$, the employment rate of displaced workers remains 20 percentage points below the employment rate of similar non-displaced workers.

There are very few studies examining employment consequences of job displacement in Europe. Most of these studies provide only descriptive information on the duration of non-employment ${ }^{4}$. Eliason and Storrie (2004) examine the employment consequences of job displacement using data for the entire private sector in Sweden. They find that displaced workers have between 1 and 2 percent higher probability of leaving the labor force and are more likely to be unemployed than similar non-displaced workers. Rege et al. (2005) investigate the impact of plant downsizing on disability pension utilization in Norway. They find that workers affected by plant downsizing are more likely than comparable workers in non-downsizing plants to use disability pensions in the following years. ${ }^{5}$

\footnotetext{
${ }^{2}$ See Bender et al. (2002), Borland et al. (2002), Burda and Mertens (1998), Carneiro and Portugal (2004) and von Wachter and Bender (2006).

${ }^{3}$ One of the commonly used data sets in the USA, for example the PSID, has only information on household heads with positive earnings in every year.

${ }^{4}$ See Abbring et al. (2002), Albæk et al. (2002) and Bender et al. (2002).

${ }^{5}$ There are also a few case studies from the Scandinavian countries that analyze in detail the outcomes over time for workers displaced from one particular plant after bankruptcy. See Westin (1990) and Edin (1988).
} 


\section{Data, Variable Definitions and Sample Con- struction}

The data on workers used in our study are derived from administrative registers and prepared for research by Statistics Norway. It covers all Norwegian residents 16-74 years old in the years 1988-1998. ${ }^{6}$ There is information about employment relationships, labor income, educational attainment, labor market status, and a set of demographic variables such as gender, age, experience and marital status. A unique person identification code allows following workers over time. Likewise, unique firm and plant codes allow identifying each worker's employer and examining whether the plant in which the worker is employed is downsizing or closing down. Plant and regional labor market characteristics such as industry, size and the rate of unemployment are also available. The match between workers and plants is in May until 1995 and in November from 1996.

The sample used in our main analysis is constructed by first identifying all male workers between age 25 and 55 who were full-time employed in manufacturing plants with at least five workers in 1991, our "base year". The year 1991 is chosen because we want to study the effect of displacement for a number of years after displacement and also to assess the employment history of workers some years before displacement. In this way a window of analysis is provided both before and after displacement. ${ }^{7}$ The age of 55 is chosen as a cut-off age primarily because the workers are still not old enough to have benefited from ordinary early pension schemes seven years on, when we assess the long-term consequences of displacement. Then, we analyze only the workers that were in the labor force and did not experience a displacement incident between 1988 and 1991. The sample obtained in this way consists of 114740 workers. We trace these workers' employment history three years before and seven years after 1991. This provides an 11-year-long panel.

Based on what happened between May 1991 and May 1992, workers are divided into five categories: exit-layoffs, early-leavers, downsizing-plant-separators,

\footnotetext{
${ }^{6}$ Data for the years 1986, 1987, 1999 and 2000 are available, but not used in this study as information about months of unemployment is unavailable.

${ }^{7}$ As a robustness exercise we have tried different base years. The pre- and post displacement patterns in employment and earnings are quite stable. There is, however, some evidence that the size of the displacement effects varies counter-cyclically. They appear to be somewhat smaller in the late 1990s when the business cycle conditions improved. See Huttunen et al (2006), Figure A1 and A2.
} 
other separators and non-separators (stayers). The first three categories define our treatment group. These are workers who were full-time employed in manufacturing in May of 1991 and became displaced from their jobs between May 1991 and May 1992. These workers will be referred to as displaced in 1991. The comparison groups are those working full-time in manufacturing in May 1991 who were not displaced from their jobs between May 1991 and May 1992.

Following the previous literature, displaced workers are understood to be individuals, who involuntarily separate from their jobs by exogenous shocks other than disability. Hence, voluntary job-movers and workers fired for cause should not be included, see for instance Fallick (1996). We conceptualize this by defining displaced workers as workers separating from plants that closed down or reduced employment by 30 percent or more in the year when the separation occurs. Displaced workers are classified as exit-layoffs if they worked in an exiting plant at the time the plant is last observed. ${ }^{8}$ Workers are classified as early-leavers if they leave a plant that exits within the next two years. They are classified as downsizing-plant-separators if they separate from a plant that reduces employment by 30 percent or more in that year. ${ }^{9}$ Note that temporary layoff with recall is a possibility in Norway and displacement includes these workers. The data allow us to identify this group and in Table 3 we present the proportion of laid-off workers with recall. The comparison or control group consists of all non-displaced workers, i.e. both stayers in downsizing plants and workers in all other continuing plants in the manufacturing sector.

We identify being out of the labor force as not having a plant identifier. Those outside of the labor force include all workers on disability pension, and on different types of work rehabilitation programs. Since the upper age in our sample is 55

\footnotetext{
${ }^{8} \mathrm{~A}$ plant is defined as an exiting plant in year $t$ if it is present in year $t$ but absent in $t+1$ and in $t+2$. If possible, we also check that the plants do not reappear after $t+2$. We remove from the sample all workers in plants that reappear. Furthermore, we check whether the workers whose plant exited between $t$ and $t+1$, work in a new plant at time $t+1$ with a new identification code, but with mostly the same workers as in the exiting plant. Such "false" plant exits may happen when more than one of the following events occur: The plant moves to a different municipality, changes industry and/or changes owner.

${ }^{9} \mathrm{~A}$ similar downsizing plant definition has been used in many previous studies, e.g., Albæk et al. (2002). The downsizing category does not include early-leavers who leave downsizing plants that are exiting in the future. Note also that for small plants, a 30 percent reduction is not a "mass layoff". Our assessment is, however, that an approach without a special size cut for defining downsizing plants is better than having an arbitrary size cut and including all workers leaving smaller plants in the non-displaced comparison group. We are using a five-employee size cut for all plants in the base year sample.
} 
in 1991 and we measure the outcome up to seven years later, those on standard early retirement schemes from the age of 63 or standard retirement schemes from the age of 67 are not included in our analysis. Hence, workers who leave the labor force one to seven years after displacement do so for health-related reasons.

Employment is measured as months of full-time equivalent employment over the year. ${ }^{10}$ This allows us to account for unemployment spells and part-time jobs as an outcome variable. Earnings are measured as annual income that provides pension points in the national security system. The included components are regular labor income, income as self-employed, and benefits received while on sick leave, being unemployed or on parental leave. The age of the worker is given in the data set. Tenure is measured in years, using the start date of the employment relationship in a given plant. Education is measured as the normalized length of the highest attained education.

Table 1 reports the mean values of the main pre-displacement variables for different worker categories. Overall, the observable differences between the various groups are small which supports our sample selection criteria. Displaced workers are slightly younger, more educated and have shorter tenure than non-displaced workers. Furthermore, displaced workers earn slightly more than non-displaced workers both one and three years prior to displacement. Exit-layoffs seem slightly older than downsizing separators and early-leavers. Among the non-displaced workers, stayers are older and have more tenure than other separators.

At the plant level we calculate the female work force, the average education level, average tenure, average worker age, plant size and plant age. Regional labor markets are defined by Statistics Norway and follow the EU standard NUTS 4, see Statistics Norway (2000). The size of the regional labor market is measured as the working age population, i.e., the population between 16 and 74 . The regional unemployment rate is calculated as the ratio of unemployed man-years to the working-age population. Table 2 provides plant- level descriptive statistics. It is revealed that the average plant size in the sample, 41 workers, is small. This reflects the general industry structure in Norway, which consists mostly of small and medium-sized firms. Exiting and downsizing plants are somewhat smaller than other plants, having on average 23 and 30 workers respectively. Average

\footnotetext{
${ }^{10}$ We have three categories of working hours and control for part-time employment as follows: $Y_{i t}=$ months of employment if a worker is working more than 30 hours a week, $Y_{i t}=$ (months of employment) $* 0,5$ if a worker is working 20-29 hours a week and $Y_{i t}=$ (months of employment $) * 0,1$ if a worker is working less than 20 hours a week.
} 
tenure is 1.3 years shorter in exiting plants and 0.8 years shorter in downsizing plants compared to the overall average. Both of these patterns are consistent with many of the exiting plants being young. On average, exiting plants are two years younger than the remaining plants.

\section{Institutional Details}

Countries differ in terms of institutional settings in the labor market and in labor relations. These differences may impact both the incidence of displacement and the size and type of associated costs. In this section we provide information on employment protection, unemployment insurance and possible exit routes from the Norwegian labor market.

\subsection{Employment protection}

According to the Norwegian law on labor relations, ${ }^{11}$ dismissals for individual reasons are limited to cases of disloyalty, persistent absenteeism, etc. In general, it is possible, but very difficult, to replace an individual worker in a given job with another worker. Norway's law on employment ${ }^{12}$ states that the general rule for laying off a worker for economic reasons is that it can occur when the job is "redundant" and the worker cannot be retained in another capacity. This regulation covers all workers regardless of how long they have been employed. Requirements for collective dismissals in Norway basically follow the common minimum standards for EU countries. It is important to note that a firm can dismiss workers not only when it is making a loss but also when it is performing poorly. There is no legal rule on the selection of workers to be dismissed, although seniority is a strong norm ${ }^{13}$.

The law on employment states that employment is terminable with one month's notice for workers with tenure of less than or equal to five years. In international comparisons, this one-month notice period is at the lower end of the spectrum. However, most workers have a three-month notice requirement for both parties to the contract. Although there is no generalized legal requirement for severance pay in Norway, agreements in the private sector require lump-sum payments to

\footnotetext{
11 "Arbeidsmiljøloven"

12 "Sysselsettingsloven"

${ }^{13}$ Seniority is institutionalized in the main collective agreement ("Hovedavtalen"), but only in situations when "all else is equal".
} 
workers aged between 50 and 55. When firms downsize, workers may also be offered pay after termination of employment, if they resign voluntarily. The period with pay from the previous employer may vary from two weeks to two years. Typically, long tenure implies more generous conditions. Other components in voluntary agreements offered to smooth the downsizing process may include job search assistance, social plans for retraining or transfer to another plant within the firm.

An interesting aspect of the Norwegian labor protection rules is access to temporary layoffs with recall possibilities. This regulation is part of the Main Agreement between the main employers' and employees' organization, and it is also observed by most firms outside the employers' organization. This agreement states that it is possible for a firm to temporarily lay off workers due to temporary changes in demand for its products etc. The firm has to pay wages for 10 days. After that, the workers are on unemployment benefit. Workers can be temporarily laid off for up to six months within an 18-month time span.

Compared to other OECD countries, Norway is ranked slightly above average for strictness regarding the use of temporary employment (OECD, 1999). Obviously, intercountry comparisons are difficult, and very few comparative studies of the overall degree of employment protection exist. A much-cited study by Emerson (1987) ranks Italy as having the strongest employment protection rules, while the UK, and, on some criteria, Denmark are at the other end of the spectrum. Norway is ranked in the intermediate range as a country with a fairly high degree of protection, together with Sweden, France and to a lesser extent Germany.

\subsection{Unemployment insurance}

The unemployment benefit system in Norway is mandatory. Given a very low threshold of labor earnings in the previous year, a worker is entitled to a benefit of 62.4 percent of the previous year's pay, or 62.4 percent of the average of the last three years. One may receive benefits for up to 156 weeks. Until 1997 there was a formal limit of 80 weeks, followed by a period of 13 weeks without benefits, and then 80 new weeks of benefit. In practice there were exemptions from these rules, so effectively there was no interruption to receiving benefits. The rules are more liberal for older workers; from the age of 60.5 years one is basically entitled to unemployment benefit until the retirement age of 67 . After the unemployment benefit period, one is entitled to means-tested social support. Unemployment 
benefits are included in our earnings measure, means-tested social support is not.

\subsection{Early retirement}

The mandatory retirement age in Norway is 67 . There is no common early retirement scheme in Norway. However, from 1989 there has been an early retirement arrangement for those covered by the main employers' and employees' organization. The age of early retirement is $62 .{ }^{14}$ As mentioned in section 3, we restricted our sample so that all workers are less than 62 years old seven years after displacement. In that way we avoid the effects of early retirement. A very common way of exiting the labor market, however, is through disability pension. In our data period the access to disability pension was very liberal, and according to Dahl et al. (2002) it is quite clear that labor market conditions were a factor when assessing people. In order to receive disability pension, a person has to document that his or her ability to earn income is reduced by at least 50 percent. The usual chain of events is first to receive sickness pension for one year and then to register for a period in a work rehabilitation program. Low income workers receive about 62 percent of last year's labor earnings in a disability pension. ${ }^{15}$ After tax this amounts to about 83 percent of the previous earnings. There also exist private early retirement schemes for workers in some firms. This may increase the earnings to cover up to 90 percent of last year's pay. Benefits received while on sick leave are included in our earnings measure, while benefits associated with work rehabilitation programs and disability pensions are not. ${ }^{16}$

\section{Descriptive Evidence}

In this section we first present the incidence of plant exits and worker displacement patterns over the business cycle. Next, we provide a detailed descriptive analysis of different end-states for workers in the short and long run. Finally, we provide some descriptive analysis supporting our choice of control group, i.e., using all other workers not displaced instead of only non-separators or non-displaced

\footnotetext{
${ }^{14}$ It was gradually reduced from 66 to 62 over the years 1989 to 1998 .

${ }^{15}$ High-income workers will receive less relative to previous income in public pensions, but are more likely to have additional private pensions. Disability pensions are supposed to give workers the same income as they would have received from the ordinary old age pension had they not become disabled.

${ }^{16}$ Benefits associated with work rehabilitation programs have been included in income earning pension points after the period for which we have data.
} 
workers staying in the labor force.

Figure 1 presents the pattern over the business cycle of exiting plants and worker displacement. All three categories of displaced workers are displayed as share of total employment for the period 1986-1996. GDP growth and the unemployment rate are used as business cycle indicators. Plant exits and displacements are both negatively correlated with GDP growth and positively correlated with the change in the unemployment rate. Hence, displacements are countercyclical. The total displacement rate varies between 5 and 11 percent. In the USA the displacement rate is about 5 percent; for most European countries it is between 5 and 10 percent and thus similar to our results (Kuhn, 2002).

Table 3 provides the main descriptive analysis of different end-states for displaced and non-displaced workers. More precisely, it demonstrates the employment status in May 1992 (short run) and November 1998 (long run) for workers separating between May 1991 and May 1992. From the upper part of the table we see that 73 percent of the displaced workers are re-employed by May 1992. If separations are equally distributed throughout the year, the average worker was displaced six months previously. Some workers, obviously, will have been displaced quite recently. For workers who are displaced from plants that will close down in the near future (early-leavers), the re-employment rate is 79 percent. Workers who stay with the dying plant until the end (exit-layoffs) are a little less likely to be re-employed within one year after separation. Their reemployment rate is 76 percent. Downsizing-plant-separators are worst off, only 68 percent are reemployed within one year after displacement. This lower re-employment rate could be because they hope to be recalled and therefore are more reluctant to accept new jobs. It could also be due to selection, i.e., workers with low productivity are laid off first (Gibbons and Katz, 1991). For the control group the employment rate is about 96 percent, clearly indicating that the displaced workers in the short run are performing worse than the rest of the workers in the economy. However, most of the non-employed displaced workers are registered as unemployed and only 2 percent are never again observed in the labor force.

The lower part of Table 3 focuses on long-term effects. The employment rate for all displaced workers increases over time and is 82 percent seven years after displacement. The employment rate for the control group has fallen to 88 percent. There is a very small difference between the employment rates of the three displacement categories seven years after displacement. The improved position of downsizing-plant-separators is consistent with their higher non-employment rate 
one year after displacement, being due to a hope for recall rather than selection. We also show that laid-off workers do have a realistic hope of being recalled. Nine percent of workers laid off from plants that do not exit in the meantime are back at the same plant seven years after the displacement incident.

The composition of the non-employed workers changes dramatically from the short to the long run. About 2 percent of the displaced workers are unemployed seven years later and about 13 percent have left the labor force. The numbers are 2 percent unemployed and 8 percent out of the labor force for the control group. This suggests that the long-term effect of displacement is a significantly higher probability of permanent job loss, about 5 percent.

Most displacement studies use firm-level data, some use plant-level data. According to Kuhn (2002, p.18) "a common practice, especially in European plant closures, involves the reallocation of large numbers of employees to other branches of the same firm". This makes the distinction between plant and firm important when analyzing displacement. When defining displacement at the plant level, one should find more workers displaced, but on average they are likely to be less severely affected, as some of the workers are not displaced from their firms. Our data contain identifiers for both plant and firm, hence, we are able to analyze this question. As far as we know, this has not been attempted before. We demonstrate that transfers to other plants within multiplant firms upon displacement are quite common. In the short run, 20 percent of the displaced workers find a new job within the firm. Workers who are displaced from exiting plants are less likely to be reemployed in the same firm than are early-leavers and downsizingplant-separators. The figures are 9, 28 and 19 percent respectively. Three percent of the displaced workers are temporarily laid off with a formal recall possibility. Such layoffs are mostly used in industries with very cyclical demand. After seven years, as many as 9 percent of workers displaced from downsizing firms are back at the plant from which they were displaced.

Examining where displaced workers end up in terms of industries, we find that 48 percent are still working in the same two-digit industry in the short run. ${ }^{17}$ Four percent move to a different two-digit manufacturing industry. As much as 20 percent move to the private service sector, while just 2 percent move to the public sector. The share of workers who change industry grows over time. Seven years

\footnotetext{
${ }^{17}$ The number for workers staying in the same two-digit industry includes workers who remain with the same firm. To the extent that these workers have been transferred to plants in other two-digit industries, this is not accounted for.
} 
after displacement, 26 percent are working in the service sector and 3 percent in the public sector. The relative share of employed workers changing industry is far higher among displaced workers than among other workers. This suggests that displacement is a forceful vehicle for industry restructuring. Finally, we notice that the originally displaced workers have a higher probability of being displaced again than other workers. The numbers are 29 percent versus 12 percent within the seven year horizon we analyze.

In Figures 2, 3 and 4 we depict the unconditional patterns for our main outcome variables; the probability of being outside the labor force, employment and earnings.

Figure 2 reports the share of workers outside the labor force after displacement in different post-displacement years for the displaced workers and all nondisplaced workers. In accordance with the pattern in Table 3, the figure demonstrates that displaced workers have a higher probability of being outside the labor force after displacement as compared to the non-displaced control group. Note that we do not distinguish between being temporarily and permanently out of the labor force in this analysis. We see that the number of workers falling out of the labor force increases roughly linearly over time. The difference in probability between displaced and non-displaced workers is about 5 percentage points. The differences is largest one year after displacement, but it is remarkably stable over time.

Figure 3 reports the share of employed workers among displaced workers, all non-displaced workers and stayers. Stayers are obviously a selected group of particularly stable workers. All non-displaced workers, on the other hand, represent the "on-going" economy where workers separate for reasons other than being displaced: they quit, become ill etc. First, note that it is quite clear from Figure 3 that using only stayers as the control group will bias the cost of displacement upwards. ${ }^{18}$ We see that there is a substantial drop in employment in the first year after displacement, but that the difference between the displaced and non-displaced workers quickly narrows. After the seventh year the differences is about 5 percentage points. Referring back to Table 3 and Figure 2, we may assume that this difference is primarily due to workers who leave the labor force.

Figure 4 reports average annual earnings. We find that displaced workers have lower earnings than non-displaced workers even before the displacement occurs.

\footnotetext{
${ }^{18}$ For instance, the seminal study of Jacobson et al. (1993) uses stayers as the comparison group.
} 
There is also evidence suggesting that the relative earnings of displaced workers start to decrease one year before the displacement. After displacement there is a clear drop in earnings, as expected. Earnings of stayers grow faster than earnings of all non-displaced workers. This suggests that comparing the earnings of displaced workers to stayers may lead us to overestimate the negative effect of displacement on earnings. However, it is clear that the difference in earnings between displaced and non-displaced workers seven years after displacement, is small.

Overall, the unconditional results in Figures 3 and 4 indicate that non-displaced workers have a better employment history than displaced workers both prior to displacement and after. After seven years, the average differences are small, particularly when looking at earnings.

\section{$6 \quad$ Regression Results}

In this section we examine the effect of job displacement by conditioning on worker, industry, firm and labor market variables. We use OLS and fixed effects regression models. This way we can control for observed and unobserved characteristics that may be correlated with displacement. Such correlations may have biased the results reported in the descriptive analysis above.

\subsection{The effect of displacement on the probability of leav- ing the labor force}

We start our analysis by investigating the effect of displacement on the probability of being out of the labor force seven years after displacement. We use the following probit specification:

$$
P\left(E_{i}\right)=\Phi\left(\mathbf{X}_{i} \beta+\mathbf{Z}_{i} \gamma+D_{i} \delta\right)
$$

$E$ (exit) is a dummy variable for being out of the labor force, $\mathbf{X}$ is a vector of observable pre- and post-displacement worker characteristics comprising years of education, age, age squared, pre displacement tenure, and pre displacement marital status. $\mathbf{Z}$ is a vector of plant and regional labor market characteristics including pre-displacement plant size, and size of the pre-displacement labor market, regional unemployment rate and dummies for pre-displacement two-digit ISIC industries. $D$ is a dummy variable for having been displaced between May 
1991 and May 1992. Hence, using a rich set of control variables, we compare similar workers in the same sectors, and similar labor markets, where the only difference is displacement.

Table 4 reports probit estimates for how displacement affects the probability of being outside the labor force in the seventh year after displacement. In accordance with the descriptive statistics, the regression results demonstrate that displaced workers have a 5.2 percentage point higher probability of being outside the labor force after displacement as compared to the non-displaced control group. This is about 0.5 percentage points higher than the unconditional results in Table 3 and Figure 2. Hence, controlling for observables does not appear to be very important.

The effect we find is larger than the effect stated by Eliason and Storrie (2004), the only comparable study we are aware of. They found that workers 21-50 years old displaced due to plant closure in Sweden had a 1 to 2 percenage point higher probability of leaving the labor force after displacement as compared to similar non-displaced workers. Their sample comprises all sectors, while we only analyze workers displaced from manufacturing firms.

One would suspect that older workers are particularly vulnerable after displacement. We investigate this by estimating the model separately for two age groups, those who are 25-44 years old in the pre-displacement year, and those who are 45-55 years old. Displacement increases the probability of leaving the labor force more for old workers than for young workers, but the difference is fairly modest. The effect is 6.2 percentage points higher for displaced workers aged 45-55 as compared to non-displaced workers of the same age, while for workers aged 25-44 it is 4.6. Further analyses of this type show that low education and being displaced from a small plant are also associated with a significantly higher probability of leaving the labor force. ${ }^{19}$

\subsection{The effect of displacement on employment}

Next, we examine the effect of displacement on months of full-time employment. Our main specification is

$$
Y_{i t}=\mathbf{X}_{i t} \beta+\mathbf{Z}_{i t} \gamma+\sum_{j=-3}^{7} D_{i t-j} \delta_{j}+\tau_{t}+\alpha_{i}+\epsilon_{i t}
$$

\footnotetext{
${ }^{19}$ See Huttunen et al (2006), Figure A4.
} 
$Y$ is months of employment. $\mathbf{X}$ and $\mathbf{Z}$ are, as above, vectors of observable worker and firm characteristics; worker's age, age squared, years of schooling, predisplacement years of tenure, pre-displacement marital status, pre-displacement plant size, pre-displacement size of the regional labor market, the regional unemployment rate and dummies for region, two-digit ISIC industry and year. Time dummies, $\tau$, are included, and in some specifications also individual fixed effects, $\alpha_{i}$. The variables of main interest are the displacement variables, $D_{i t-j}$. These are dummy variables indicating whether a displacement occurs at time $t-j, t$ being the observation year. Job loss is allowed to affect labor market outcomes four years before its occurrence and seven years after its occurrence, hence $j=-3 \ldots, 0, \ldots 7$.

Table 5 reports the effect of displacement on months of full-time employment. The first column reports results for all workers, i.e., the average over a sample including workers who are out of the labor force. The second column reports results using only a sample of workers who are in the labor force in the observation year. Displacement happens between 1991 and 1992, and we do not control for displacement after this time period. From Table 3 we see that the treatment group, i.e. those displaced between 1991 and 1992, experience more displacements in the years 1992 to 1998 than other workers. We consider this higher displacement probability a causal effect of the displacement in 1991.

The coefficients on the variable $D_{t}$, represent the effect in 1991. Given that all job relationships lasted at least until May that year, it will pick up both the effect of working for a troubled firm at the verge of closure or downsizing, and some immediate effects of displacement. If displacements happen evenly throughout the year, the "average" displacement would take place in November 1991. Since the average displacement date is towards the end of the year, we expect to see at least as strong effect in the calendar year 1992 as in 1991. The effect for the calendar year 1992 is picked up by the dummy variable "Displaced at $t-1$ " $\left(D_{t-1}\right)$.

The OLS estimates indicate a negative and significant employment effect for all years before and after displacement. ${ }^{20}$ Displaced workers work on average 2.7 months less in the year following displacement as compared to similar non-

\footnotetext{
${ }^{20} \mathrm{~A}$ large share of the workers will work 12 or 0 months, so our dependent variable is limited and not normally distributed. Given our large sample, this should not invalidate the OLS results, but as a robustness check, we have also used a Tobit specification. The qualitative results in both cases are the same.
} 
displaced workers. The effect diminishes over time and is 0.6 months seven years after displacement. If we exclude workers who leave the labor force from the sample, the first year average effect is 2.2 months and the seventh year effect is only 0.14 .

The pre-displacement employment history in Figures 3 and 4 suggests that there are more low productivity workers among the displaced workers than in the control group. If this is the case, the OLS results will be biased and overstate the negative effect of displacement. One way to correct for this potential selection bias is to include individual specific fixed effects to control for unobserved worker characteristics. Implementing this, we demonstrate that the effects of displacement become slightly smaller. The first-year effect for the full sample is reduced from 2.7 months to 2.5 months, and the seventh-year-effect is reduced from 0.6 to 0.4. Note that the fixed effects specification basically measures the effect relative to employment three years before the displacement incident. This displacement dummy is removed in order to avoid perfect collinearity. The OLS specification without fixed effects suggests that there is an early negative effect of displacement already at that time of about 0.2 months, corresponding to the difference between the OLS and the fixed effects results. The fixed effects results provide an unbiased estimate of the displacement effect, only if the relatively lower earnings of the displaced workers are due to unobservable permanent differences between the displaced and the non-displaced workers, and not due to the fact that they are working in a troubled firm. Lacking data to trace the workers' employment histories further back in time, we cannot identify whether this coefficient reflects selection or the effect of working for a troubled firm. Jacobson et al. (1993) report that the effect of displacement appears in their data about three years prior to displacement but not before. In our set up, the third pre-displacement year is the period three to four years before the displacement. Thus it is realistic to assume that the relatively low employment and earnings of displaced workers at that time do not refer to a future displacement event.

\subsection{The effect of displacement on earnings}

Having examined the effect of displacement on employment, we next examine the effect on earnings. We use the same specification (2), but the dependent variable, $Y$, is now the natural log of income that qualifies for pension from the national security system. This includes unemployment benefits and benefits while on sick 
leave.

Table 6, column 1, reports OLS results for a sample consisting of all workers. We see that in the displacement year, the average earnings loss for displaced workers is 4.3 percent relative to similar workers who were not displaced. In the first full calendar year after displacement, the average earnings loss is 8.8 percent and two years after, the earnings loss peaks at 11.1 percent. This monotonic increase in the earnings loss early on may appear puzzling, particularly as it was revealed in Table 5 that the employment effect peaks in the first year after displacement. We believe that we have captured the effect of some workers receiving full wage from their previous employer as part of their layoff agreement. Such compensation schemes may last from two weeks to two years, cf. Section 4.1. From year two to seven after the displacement, the average earnings loss decreases monotonically. In year seven the earnings loss is 3.7 percent and still significant ${ }^{21}$. The results of the fixed effects specification are very similar to the OLS results.

When using the sample of employed workers only, the results are very different. Looking at the fixed effects results we find no effect in the first year after displacement. Looking at the OLS results we find a 2.1 percent premium in the first year after displacement. In the following years, we estimate an earning loss which peaks in the forth year after displacement, regardless of specification. The loss, however, is essentially vanished by year 7 . The explanation for this pattern is that we now have an unbalanced panel. As demonstrated in Figure 3, displaced workers are quite likely to be outside the labor market or unemployed in the year immediately following the job loss. The group of workers who manage to find employment immediately after the job loss is not a representative sample of displaced workers ${ }^{22}$. From the second year after job displacement, however, employment among the displaced workers starts to increase. Thus the sample of workers re-employed in these years is a less selected group. All in all, this shows that the magnitude of the earnings losses is very sensitive to the sample that we are using. As we have stressed already, analyses based on re-employed workers only will seriously underestimate the costs of job displacement.

In order to get a better grip on this selection issue, we examine how the earnings losses vary by workers' post-displacement labor market status. I.e., we include dummies for workers' labor market status and interactions between the

\footnotetext{
${ }^{21}$ Interestingly, this is larger than the unconditional estimate in Figure 3.

${ }^{22}$ Many of them have probably been transferred to a different plant within the firm.
} 
displacement dummies and the dummies that describe the workers' labor market status in different post-displacement years:

$$
Y_{i t}=\mathbf{X}_{i t} \beta+\mathbf{Z}_{i t} \gamma+\sum_{j=-3}^{0} D_{i t-j} \delta+\mathbf{S}_{i t} \eta+\sum_{j=1}^{7} \mathbf{S}_{i t} \times D_{i t-j} \theta_{j}+\tau_{t}+\alpha_{i}+\epsilon_{i t}
$$

$\mathbf{S}_{i t}$ is a vector of dummy variables that describes worker $i$ 's labor market status in year $t$, i.e. whether he is employed, unemployed or outside the labor force.

Table 7 reports the results. We find that there are huge differences in the earnings losses according to the workers' post-displacement labor market status. According to the OLS specification, displaced workers who are re-employed suffer no long-term earnings losses as compared to similar non-displaced workers. Workers who become unemployed suffer a significant earnings loss that increases over time, but displaced workers do not suffer a larger earnings loss from unemployment than non-displaced workers. Workers leaving the labor force face the largest estimated earnings loss, but unfortunately, this loss cannot be measured correctly as our income variable does not include the public benefits received by this group. Their most likely sources of income are disability pension, work rehabilitation benefits and means tested social support. Nonetheless, it is interesting to note that displaced workers who leave the labor force perform better than non-displaced workers who leave the labor force in terms of measured income components.

The lower panel of table 7 reports the results of fixed effects specification. We find that the estimated earnings loss for re-employed displaced workers increases, while the estimated earnings loss for unemployed workers and workers out of the labor force decreases. This shows that there is positive selection into employment. The average long-term earnings loss for re-employed workers is 1.4 percent.

There may be important heterogeneity in the earnings losses of re-employed displaced workers. Table 8 reports the results of a regression using employed workers only, and where the displacement effects are allowed to vary depending on the firm and sector where the displaced workers find new employment. The regression does not include dummies for post displacement industry. Thus the comparison group is all non-displaced employed workers with similar observable pre-displacement characteristics. We distinguish between displaced workers who are re-employed in the same firm, those re-employed in a different firm within 
the same two-digit industry, those re-employed in another manufacturing industry, those re-employed in the private service sector and those re-employed in the public sector. The OLS-results show that the relatively few displaced manufacturing workers who are re-employed in the public sector suffer significantly bigger earnings reductions than those who are re-employed within manufacturing or in private services. Displaced workers who are re-employed in private services actually earn a bit more than non-displaced workers with similar pre-displacement characteristics. The same is true for workers who find new employment in the firm from which they were displaced, while those moving to a different two-digit industry suffer a small short-term loss, and those moving to another manufacturing industry suffer a rather substantial loss both in the short and long run.

Moving to the fixed effects specification presented in the lower panel, we see that the OLS results to a large extent are driven by sorting on unobservable characteristics. The most productive workers seem to stay within the firm they were displaced from or transfer to the private sector. The least productive workers transfer to the public sector. All workers suffer some short-term losses, even those re-employed within the same firm. The only workers that seem to suffer a permanent earnings loss are those who move to the public sector. Their earnings loss is reduced from 23.4 percent in the OLS specification to 13.5 percent. At least some of this reduction can be considered a compensating differential associated with generous pension plans, high job stability and other amenities in the public sector. The average wage gap between manufacturing workers and workers in the public sector with similar observable characteristics is about 15 percent.

\subsection{The effect of displacement by displacement type}

As a final analysis, we investigate how the effect of displacement varies between different displacement categories; exit-layoffs, early-leavers and downsizing-plantseparators. The latter two groups may be a nonrandom sample of the plants' employees. The troubled plants have an obvious incentive to lay off less-productive workers, or more precisely, workers with low productivity relative to their wage. Furthermore, workers with relatively good external market opportunities and little firm-specific human capital may be more likely to quit when their employment relationship becomes uncertain. Since a plant closing is often preceded by a period of significant downsizing, this has ramifications also for the exit-layoffs. If workers who leave during a downsizing period are a selected group, workers who 
stay until the end will also be selected..$^{23}$ In order to explore possible differences between the three displacement categories, we estimate a model in which the displacement effect is allowed to differ between these groups.

The results in Table 9 confirm negative employment effects for all displacement categories. The short-run negative effect is, however, weaker for early-leavers than for the other two categories. Focusing on the fixed effects results, early-leavers work on average 1.7 months less in the year immediately following displacement. For exit-layoffs the average employment reduction immediately after displacement is 2.5 months. The effect is strongest for the downsizing-plant-separators. They work on average 3.0 months less in the year immediately following displacement than similar non-displaced workers. The early-leavers category may consist of workers who have better outside opportunities and who leave the plant voluntarily before the closure. In the long run the employment reduction is small for all groups, about 0.4 months. As we discussed in connection with our descriptive analysis in section 5, this suggests that the difference between exit-layoffs and downsizing-plant-separators in the short-run reflects differences in search behavior rather than selection.

The lower panel of Table 9 reports earnings regressions for the different displacement categories. We find that exit-layoffs experience a far larger earnings loss after displacement than the two other groups. Focusing again on fixed effects results, their earnings loss peaks at 16.4 percent two years after displacement and is 10.1 percent even in the long run. Early-leavers have an earnings loss of 4.9 in the short run and a wage premium of 2.5 percent in the long run. Downsizingplant-separators have an earnings loss of 10.6 percent in the short run and a wage premium of 4.5 percent in the long run. The difference between exit-layoffs and early-leavers may reflect that the latter category is a selected sample of workers with good outside options. The long-run difference between exit-layoffs and downsizing-plant-separators is more surprising, but it may partly reflect the fact that 9 percent of the latter group are recalled to their old plant within a periode seven years, cf. Table 3.

\footnotetext{
${ }^{23}$ Lengermann and Vilhuber (2002) study the employment flows from plants prior to plant closure. They find important differences between the quality composition of workers who leave the plant before the closure and those who stay until the closure. Cf. also Bowlus and Vilhuber (2002) and Hamermesh and Pfann (2001).
} 


\section{Concluding remarks}

We have examined the impact of displacement on workers' employment and earnings using administrative linked employer-employee data from Norway. We have focused on workers displaced by plant closure and on workers separating from plants that downsize by $30 \%$ or more in 1991, the base year of our analysis. The comparison group is workers in firms not exiting or downsizing significantly.

Our descriptive analysis demonstrates that displacement is an important mechanism for industry restructuring and that the employment effects of displacement are far more pronounced than the earnings effects both in the short and long run. Our first main result is that displacement increases the probability of leaving the labor force by five percentage points. This is an important result and suggests that displacement studies with a sample restricted to workers in the labor force may severely underestimate the costs of displacement. In an international context, our result may perhaps be considered an upper bound on the probability of leaving the labor force. First, labor force attendance is very high in Norway as compared to most countries. This may imply many "marginal workers" in the labor force, and a shock such as a displacement incident may push them out. Second, as we described in the section on labor market institutions, the incentives for leaving the labor force early are strong in Norway, and probably better than in most countries.

Workers who are displaced and who do not permanently leave the labor force, work on average 2.2 months less in the year following displacement as compared to similar non-displaced workers. Seven years after displacement, they work on average only a few days less than non-displaced workers. Hence, the effect for those in the labor force is very small in terms of unemployment. The average effect of displacement on earnings for re-employed workers is also small, particularly compared to US studies. One reason for this is the small wage differences among Norwegian workers. Norway has for years had one of the smallest wage dispersions among the OECD countries (See, for instance, Salvanes and Førre, 2003). The low wage dispersion can be linked to centralized wage bargaining. Centralized wage bargaining implies that there is a minimum wage for blue-collar workers bargained at sector level (see Holden, 1998). Given that most re-employed workers find a new job in the same sector as their previous job, this minimum wage restriction is binding. In many other European countries, mandatory minimum wage laws provide the same effect. The lack of mandatory minimum wages in Portugal 
is probably the reason why the recent study by Carneiro and Portugal (2004) revealed large wage reductions for displaced workers.

To assess heterogeneity in the costs of displacement we categorize workers by the sector of re-employment and whether they find new employment within their old firm. All workers suffer some short-term losses, even those re-employed within their old firm. For workers that do not move to the public sector this loss is within the interval 2-5 percent. Only the relatively few workers re-employed in the public sector experience a significant long term loss. Their estimated longterm loss is 13.5 percent. This is not particularly large compared to the average wage differential between the private and public sector. Contrasting the fixed effects specification with OLS results suggests that the most productive workers stay within the firm they were displaced from or transfer to the private sector. The least productive workers transfer to the public sector.

\section{References}

[1] Abbring, Jaap H., Gerard J. van den Berg, Pieter A. Gautier, A. Gijsbert C. van Lomwel, Jan C. van Ours, Christopher J. Ruhm (2002): "Displaced Workers in the United States and the Netherlands", in Peter J. Kuhn (ed.): Losing Work, Moving On. International Perspectives on Worker Displacement, W. E. Upjohn Institute for Employment Research. Kalamazoo, USA.

[2] Albæk, Kartsen, Marc van Audenrode and Martin Browning (2002): "Employment Protection and the Consequences for Displaced Workers", in Peter J. Kuhn (ed.): Losing Work, Moving On. International Perspectives on Worker Displacement, W. E. Upjohn Institute for Employment Research. Kalamazoo, USA.

[3] Bender, Stefan, Christian Dustmann, David Margolis, and Costas Meghir (2002): "Worker Displacement in France and Germany", in Peter J. Kuhn (ed.): Losing Work, Moving On. International Perspectives on Worker Displacement, W. E. Upjohn Institute for Employment Research. Kalamazoo, USA.

[4] Borland, Jeff, Paul Gregg, Genevieve Knight and Jonathan Wadsworth (2002): "They Get Knocked Down. Do they Get Up Again?", in Peter J. Kuhn (ed.): Losing Work, Moving On. International Perspectives on Worker 
Displacement, W. E. Upjohn Institute for Employment Research. Kalamazoo, USA.

[5] Bowlus, Audra and Lars Vilhuber (2002): "Displaced workers, early leavers, and re-employment wages", LEHD Technical Working Paper No. TP-200218

[6] Burda, Michael C, and Antje Mertens (1998): "Wages and Worker Displacement in Germany", CEPR Discussion Paper No. 1869

[7] Carneiro, Anabela and Pedro Portugal (2004): "Wages and the risk of displacement", Mimeo

[8] Chan, Sewin and Ann Huff Stevens (2001): "Job Loss and Employment Patterns of Older Workers", Journal of Labor Economics, 2001, Vol. 19(21), pp. $484-520$

[9] Dahl, Svenn-Åge, Nilsen, Øivind A. and Vaage, Kjell (2002): "Work or retirement? Exit routes for Norwegian elderly", Applied Economics, Vol. $32(14)$, pp. 1865-1876

[10] Edin, Per-Anders (1988): Individual Consequences of Plant Closures, PhD thesis, Department of Economics, Uppsala University.

[11] Eliason, Marcus and Donald Storrie (2004): "The Echo of Job Displacement", ISER Working Papers, Number 2004-20

[12] Emerson, M. (1987): "Labour Market Flexibility and Jobs: A Survey of Evidence from OECD Countries with Special Reference to Europe: Comments" in R. Lyard, and L. Calmfors (eds.): The Fight against Unemployment: Macroeconomic Papers from the Centre for European Policy Studies, pp. 77-84, MIT Press

[13] Fallick, Bruce C. (1996): "A Review of the Recent Empirical Literature on Displaced Workers", Industrial and Labor Relations Review, Vol. 50(1), pp. $5-16$

[14] Gibbons, Robert and Lawrence F. Katz (1991): "Layoffs and Lemons", Journal of Labor Economics, Vol. 9(4), pp. 351-380 
[15] Hamermesh, Daniel (1987): "The Costs of Worker Displacement", Quarterly Journal of Economics, Vol. 102(1), pp. 51-76

[16] Hamermesh, Daniel (1989): "What Do We Know About Worker Displacement in the US", Industrial Relations, Vol. 28(1), pp. 51-59

[17] Hamermesh, Daniel and Gerard Pfann (2001): "Two-Sided Learning, Labor Turnover, and Worker Displacement", IZA Discussion Paper No. 381, Institute for the Study of Labor

[18] Holden, Steinar (1998): "Wage Drift and the Relevance of Centralized Wage Setting", Scandinavian Journal of Economics, 100(4), pp. 711-731

[19] Huttunen, Kristiina, Jarle Møen and Kjell G. Salvanes (2006): "How destructive is creative destruction? The costs of worker displacement", Discussion Paper 11, Department of Economics, Norwegian School of Economics and Business Administration

[20] Jacobson, Louis S., Robert J. LaLonde and Daniel G. Sullivan (1993): "Earnings Losses of Displaced Workers", American Economic Review, Vol. 83(4), pp. 685-709

[21] Kletzer, Lori G. (1998): "Job Displacement", Journal of Economic Perspectives, Vol. 12(1), pp. 115-36

[22] Kletzer, Lori G. and Robert W. Fairlie (2003): "The Long-Term Costs of Job Displacement for Young Adult Workers", Industrial and Labor Relations Review, Vol. 56(4), pp. 682-698

[23] Lengermann, Paul A. and Lars Vilhuber (2002): "Abandoning the Sinking Ship: The Composition of Worker Flows Prior to Displacement", LEHD Technical Working Paper No. TP-2002-11

[24] Kuhn, Peter J. (2002): Losing Work, Moving On. International Perspectives on Worker Displacement, W. E. Upjohn Institute for Employment Research. Kalamazoo, USA.

[25] OECD (1999): Employment Outlook, OECD, Paris 
[26] Rege, Mari, Kjetil Telle and Mark Votruba (2005): "The Effect of Plant Downsizing on Disability Pension Utilization", Discussion Papers 435, Statistics Norway

[27] Ruhm, Christopher J. (1991a): "Are Workers Permanently Scarred by Job Displacements?", American Economic Review, Vol. 81(1), pp. 319-324

[28] Ruhm, Christopher J. (1991b): "Displacement Induced Joblessness", Review of Economics and Statistics, Vol. 73(3), pp. 517-522

[29] Salvanes, Kjell G. and Svein E. Førre (2003): "Effects on Employment of Trade and Technical Change: Evidence from Norway," Economica, Vol. 70, pp. 293-329

[30] Statistics Norway (2000): "Classification of Economic Regions", Official Statistics of Norway C616, Statistics Norway

[31] Stevens, Ann Huff (1997): "Persistent Effects of Job Displacement: The Importance of Multiple Job Losses", Journal of Labor Economics, Vol. 15(1), pp. $165-188$

[32] von Wacher, Till and Stefan Bender (2006): "In the Right Place at the Wrong Time - The Role of Firms and Luck in Young Workers' Careers", forthcoming in The American Economic Review

[33] Westin, Steinar (1990): "The Structure of a Factory Closure: Individual Responses to Job-loss and Unemployment in a 10-year Controlled Follow-up Study", Social Science and Medicine, Vol. 31(12), pp. 1301-1311 
Figure 1

Business cycle indicators, plant exit rate and share of displaced workers

in Norway 1986-1996

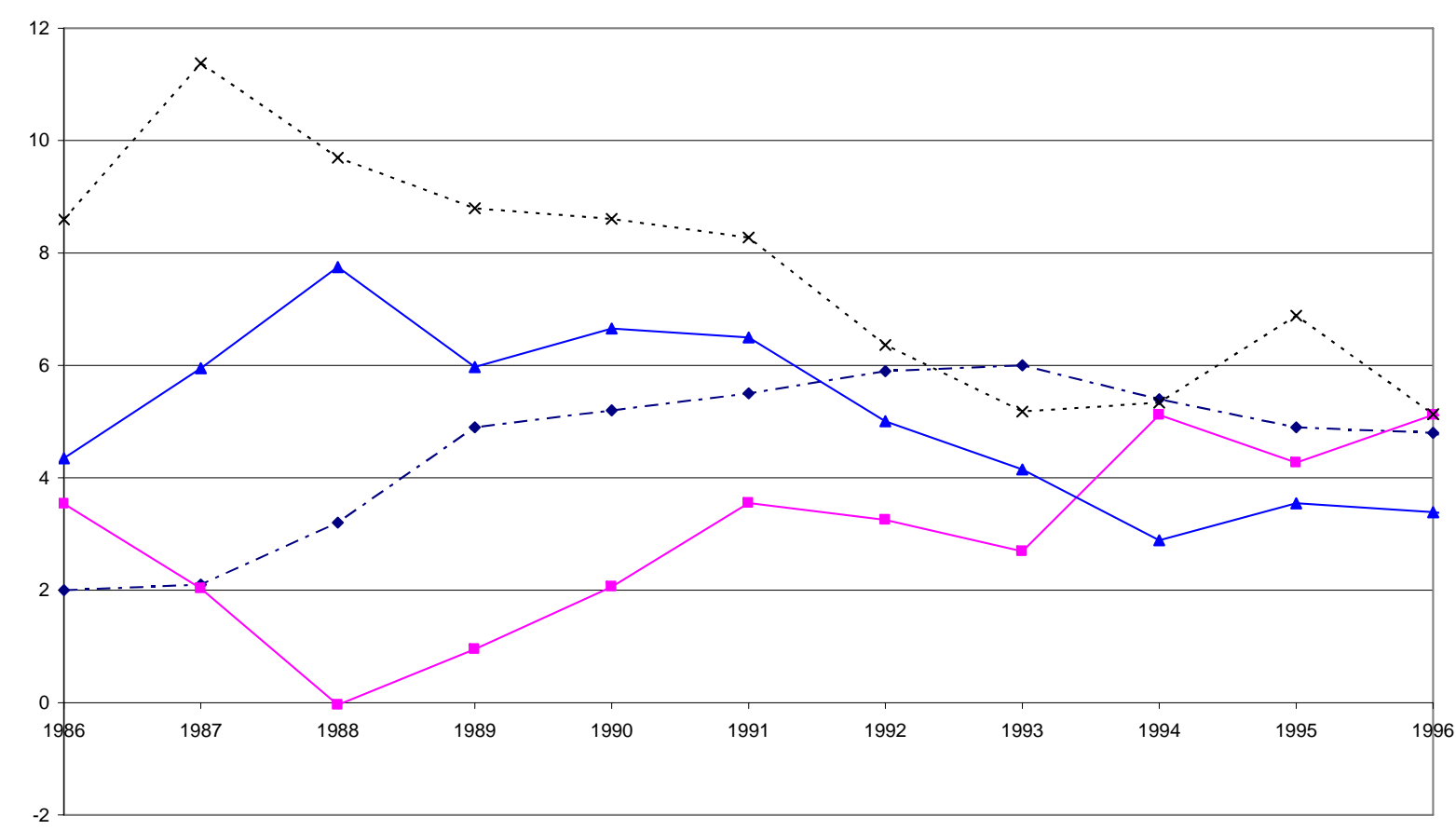

$-\cdots$ Unemployment rate $\longrightarrow$ Gdp growth rate $\longrightarrow$ Exit-rate $\cdots * \cdots$ Share of displaced workers

The growth rate is the percent change in GDP from year $\boldsymbol{t}-1$ to $\boldsymbol{t}$. A plant is defined as an exiting plant if it is present at $\boldsymbol{t}$, but absent at $\boldsymbol{t}+1$ and $\boldsymbol{t}+2$ (and later if that is possible to check). The displacement rate is the share of workers who were displaced from their jobs between $\boldsymbol{t}$ and $\boldsymbol{t}+1$ among workers who were working full time in plants with at least 5 employees in period $\boldsymbol{t}$. The displaced workers can be divided into three sub categories: Workers who separated between $\boldsymbol{t}$ and $\boldsymbol{t}+1$ from plants that exited between $\boldsymbol{t}$ and $\boldsymbol{t}+1$ (exitlayoffs), workers who separated between $\boldsymbol{t}$ and $\boldsymbol{t}+1$ from plants that exited between $\boldsymbol{t}+1$ and $\boldsymbol{t}+2$ (early-leavers), and workers who separated between $\boldsymbol{t}$ and $\boldsymbol{t}+1$ from plants that reduced their size by more than $30 \%$ between $\boldsymbol{t}$ and $\boldsymbol{t}+1$ (downsizing plant separators). 


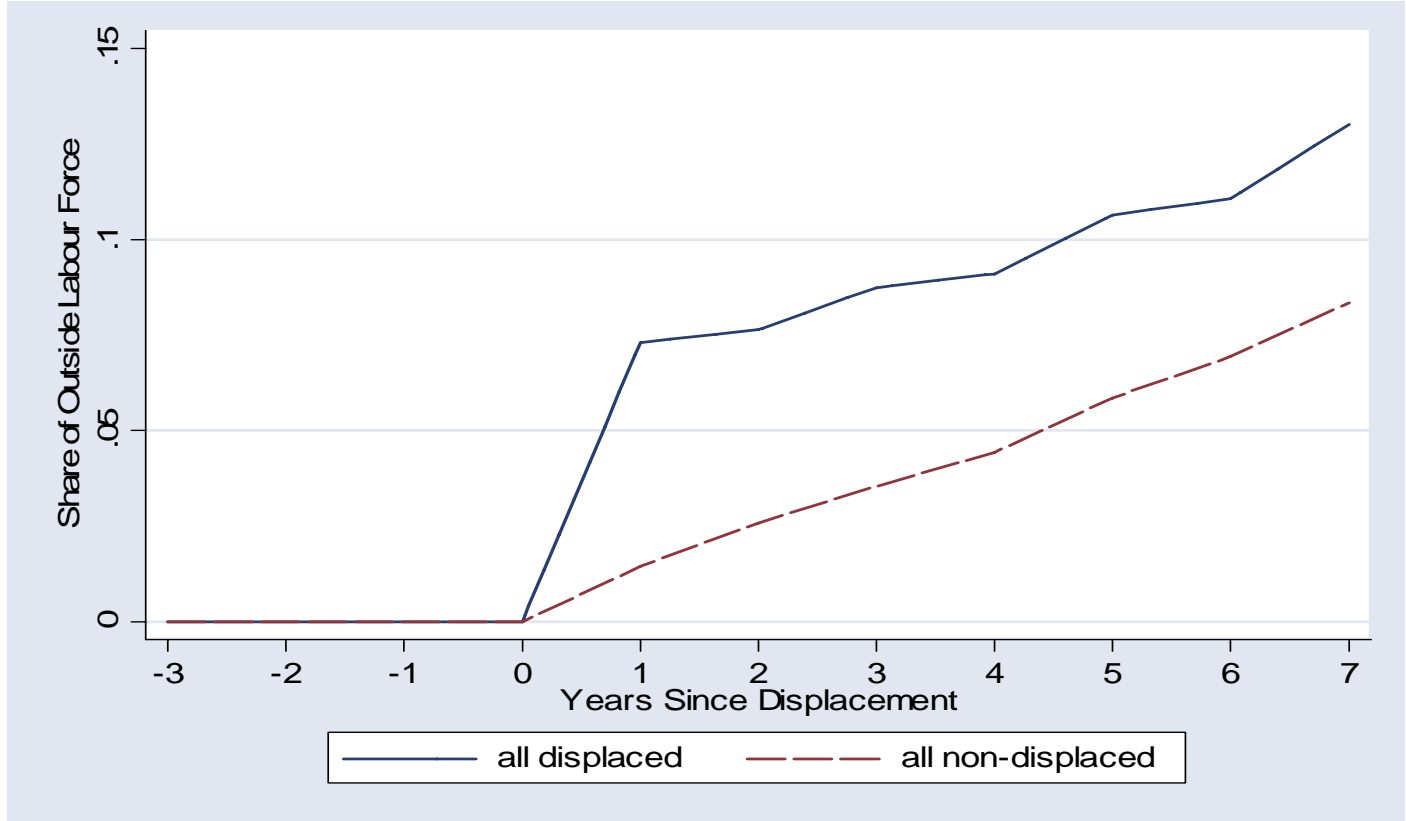

The sample consists of 25-55 year old male workers full time employed in manufacturing in 1991 (year zero), who were in the labor force and not displaced from their jobs in the previous three years. 
Figure 3

The share of employed before and after displacement

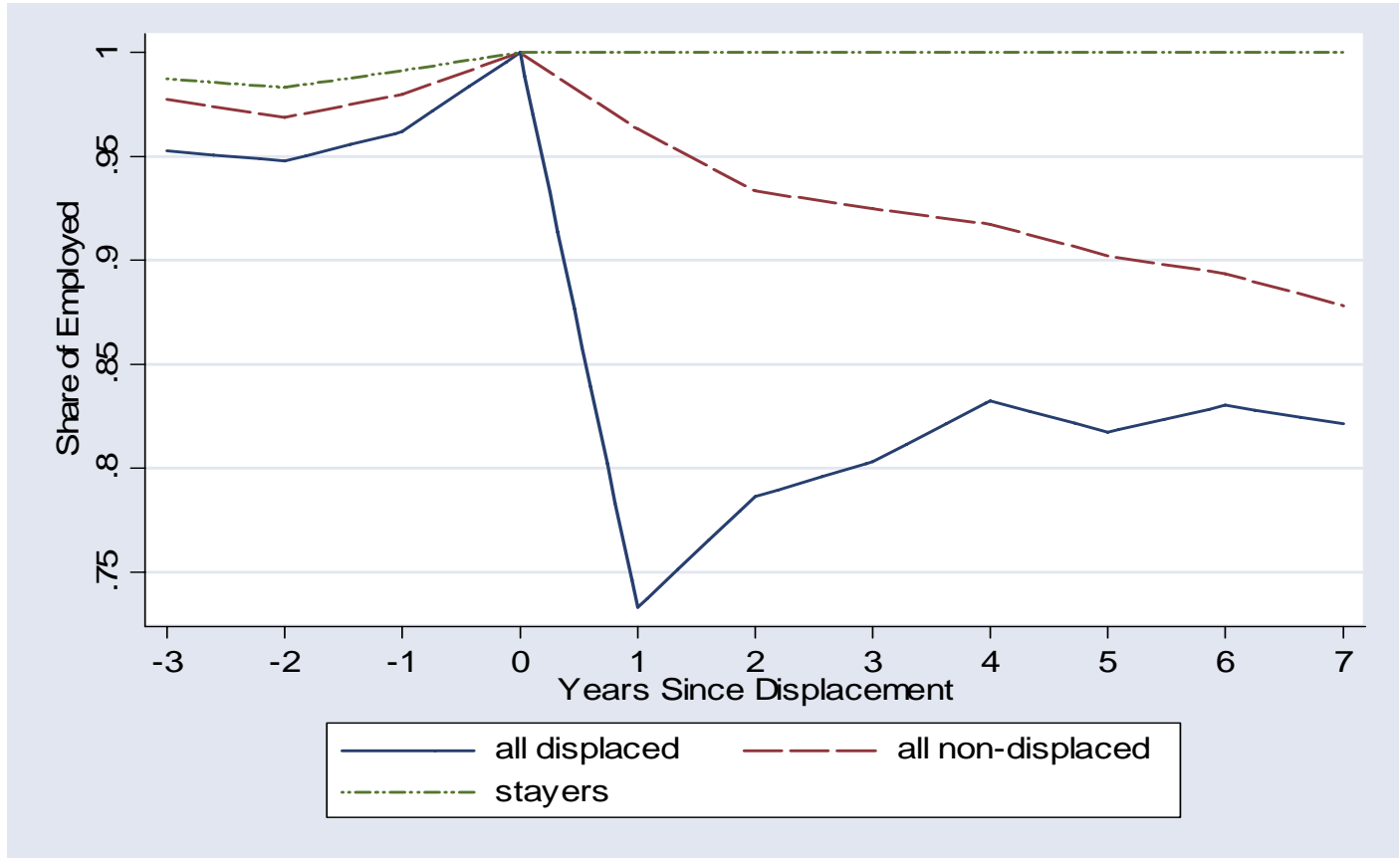

The sample consists of 25-55 year old male workers full time employed in manufacturing in 1991 (year zero), who were in the labor force and not displaced from their jobs in the previous three years. 


\section{Figure 4 Annual earnings before and after displacement}

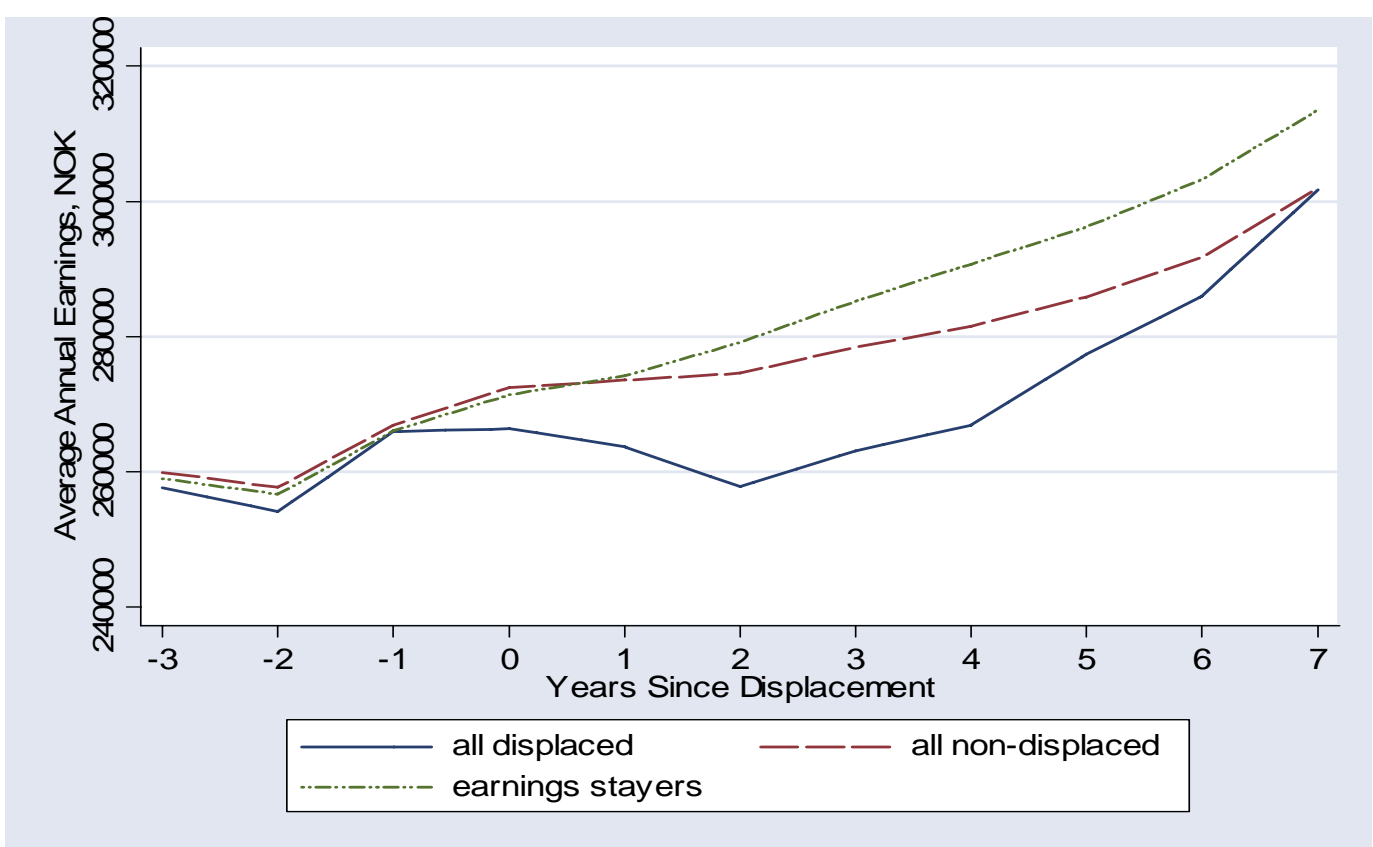

The sample consists of 25-55 year old male workers full time employed in manufacturing in 1991 (year zero), who were in the labor force and not displaced from their jobs in the previous three years. 


\section{Table 1}

Sample means of selected pre-displacement worker characteristics by displacement status

\begin{tabular}{|c|c|c|c|c|c|c|c|c|}
\hline & All workers & $\begin{array}{l}\text { All displaced } \\
\text { workers }\end{array}$ & Exit-layoffs & Early leavers & $\begin{array}{l}\text { Downsizing } \\
\text { plant separators }\end{array}$ & $\begin{array}{l}\text { All non-displaced } \\
\text { workers }\end{array}$ & Stayers & Separators \\
\hline Age at $t$ & 39.41 & 38.75 & 39.34 & 38.31 & 38.62 & 39.45 & 39.62 & 37.75 \\
\hline Education at $t$ & 10.73 & 10.92 & 10.55 & 11.32 & 10.93 & 10.72 & 10.69 & 11.03 \\
\hline Tenure at $t$ & 7.31 & 6.49 & 7.23 & 7.51 & 5.29 & 7.36 & 7.55 & 5.47 \\
\hline Married at $t$ & 0.65 & 0.62 & 0.66 & 0.59 & 0.61 & 0.65 & 0.66 & 0.56 \\
\hline Earnings at $t-1$ & 235435 & 230318 & 210957 & 244827 & 234731 & 235764 & 236641 & 226931 \\
\hline Earnings at $t-3$ & 199796 & 198174 & 190616 & 204279 & 199610 & 199900 & 200116 & 197726 \\
\hline No. of observations & 114740 & 6935 & 2096 & 1904 & 2935 & 107805 & 98061 & 9744 \\
\hline
\end{tabular}

Displacements happened between May 1991 and May 1992. The sample consists of 25-55 year old male workers full time employed in manufacturing plants with at least five employees in 1991 (year $t$ ), who were in the labor force and not displaced from their jobs in the previous three years. 


\begin{tabular}{|c|c|c|c|c|}
\hline & All plants & Exiting plants & Downsizing plants & Other plants \\
\hline Employment at $t$ & 40.53 & 22.58 & 30.39 & 42.75 \\
\hline Employment at $t-1$ & 40.50 & 24.28 & 30.56 & 42.58 \\
\hline Average worker age at $t$ & 39.74 & 38.91 & 39.45 & 39.83 \\
\hline Average tenure at $t$ & 5.61 & 4.36 & 4.86 & 5.76 \\
\hline Average schooling at $t$ & 10.30 & 10.30 & 10.22 & 10.31 \\
\hline Share of female at $t$ & 0.28 & 0.28 & 0.28 & 0.28 \\
\hline Share of married at $t$ & 0.59 & 0.56 & 0.57 & 0.59 \\
\hline Plant age at $t$ & 18.30 & 16.49 & 16.65 & 18.54 \\
\hline Employment growth. $t-1$ to $t$ & 0.00 & -0.07 & -0.01 & 0.00 \\
\hline Employment growth. $t$ to $t+1$ & -0.03 & - & -0.50 & 0.01 \\
\hline Share of plants in "sunset" industries & 0.08 & 0.06 & 0.11 & 0.08 \\
\hline Size of the regional labor market & 62256 & 60518 & 56153 & 62984 \\
\hline Regional rate of unemployment*100 & 3.24 & 3.27 & 3.22 & 3.24 \\
\hline No. of observations & 6509 & 405 & 509 & 5595 \\
\hline
\end{tabular}

The sample consists of manufacturing plants with at least five employees in 1991 (year $t$ ). The plants are categorized based on what happens with employment from year $t$ to $t+1$. Plant age is censored at 26. The sunset industries are 5 digit-industries with 15 percent (or more) decline in relative employment between 1980 and 1990 . The employment growth rates are weighted by plant size in the beginning of the period (at $\mathrm{t}-1$ or at $\mathrm{t}$ ). 


\begin{tabular}{|c|c|c|c|c|c|}
\hline One year after & All displaced & Exit -Layoffs & Early-Leavers & $\begin{array}{l}\text { Downsizing } \\
\text { separators }\end{array}$ & Other workers \\
\hline Employed & 73.29 & 75.57 & 79.10 & 67.90 & 96.34 \\
\hline same plant & - & - & - & - & 90.96 \\
\hline different plant within the same firm & 19.64 & 9.06 & 27.94 & 21.81 & 1.78 \\
\hline different firm within the same industry & 28.26 & 47.90 & 20.64 & 19.18 & 1.42 \\
\hline other two digit manufacturing industry & 4.33 & 2.48 & 8.51 & 2.93 & 0.32 \\
\hline private service & 19.52 & 14.84 & 20.33 & 22.35 & 1.58 \\
\hline public service & 1.54 & 1.29 & 1.68 & 1.64 & 0.28 \\
\hline Not-employed & 26.71 & 24.43 & 20.90 & 32.10 & 3.66 \\
\hline temporary laid off & 2.94 & 1.05 & 3.10 & 4.19 & 0.53 \\
\hline registered as unemployed & 15.91 & 15.89 & 11.4 & 18.84 & 1.39 \\
\hline temporarily outside the labor force & 4.86 & 4.29 & 3.99 & 5.83 & 0.90 \\
\hline permanently outside the labor force & 2.44 & 2.91 & 1.79 & 2.52 & 0.54 \\
\hline Dead or Moved Abroad (Not observable in the data) & 0.56 & 0.29 & 0.63 & 0.72 & 0.30 \\
\hline Seven years after & All displaced & Exit -Layoffs & Early-Leavers & $\begin{array}{c}\text { Downsizing } \\
\text { separators }\end{array}$ & Other workers \\
\hline Employed & 82.15 & 82.59 & 82.35 & 81.70 & 87.83 \\
\hline same plant & 3.98 & - & - & 9.40 & 51.08 \\
\hline different plant within the same firm & 9.92 & 6.25 & 21.85 & 4.80 & 6.51 \\
\hline different firm within the same industry & 30.74 & 46.09 & 14.71 & 30.19 & 13.01 \\
\hline other two digit manufacturing industry & 7.70 & 6.35 & 9.72 & 7.36 & 3.08 \\
\hline private service & 26.47 & 21.23 & 32.77 & 26.13 & 12.50 \\
\hline public service & 3.33 & 2.67 & 3.31 & 3.82 & 1.65 \\
\hline Not-employed & 17.85 & 17.41 & 17.65 & 18.30 & 12.17 \\
\hline registered as unemployed & 2.48 & 2.58 & 1.89 & 2.79 & 1.67 \\
\hline outside the labor force & 13.06 & 12.65 & 13.61 & 13.01 & 8.34 \\
\hline Dead or Moved Abroad (Not observable in the data) & 2.31 & 2.19 & 2.15 & 2.49 & 2.15 \\
\hline Share of workers that are displaced btw years 1 and 6 & 28.81 & 55.06 & 15.23 & 18.88 & 12.26 \\
\hline No. of observations & 6935 & 2096 & 1904 & 2935 & 107805 \\
\hline
\end{tabular}

Displacements happened between May 1991 and May 1992. The sample consists of male workers, who were 25-55 year old and full time employed in manufacturing plants with at least five employees in 1991, and who were in the labor force and not displaced from their jobs in the previous three years. Permanently outside the labor force means outside the labor force at least until the seventh year after displacement. Temporary laid off workers have a formal recall possibility and are registered as unemployed. 


\begin{tabular}{llccccc}
\hline & \multicolumn{2}{c}{ All } & \multicolumn{2}{c}{ Old } & \multicolumn{2}{c}{ Young } \\
\hline Age & $-0.025^{* * *}$ & $(0.001)$ & $-0.264^{* * *}$ & $(0.022)$ & 0,001 & $(0.003)$ \\
Age squared & $0.000^{* * *}$ & $(0.000)$ & $0.002^{* * *}$ & $(0.000)$ & 0,000 & $(0.000)$ \\
Years of schooling & $-0.007^{* * *}$ & $(0.000)$ & $-0.010^{* * *}$ & $(0.001)$ & $-0,007^{* * *}$ & $(0.000)$ \\
Pre displacement tenure & $-0.002^{* * *}$ & $(0.000)$ & $-0.001^{* * *}$ & $(0.000)$ & $-0,003^{* * *}$ & $(0.000)$ \\
Pre displacement marital status & $-0.026^{* * *}$ & $(0.002)$ & $-0.046^{* * *}$ & $(0.005)$ & $-0,021^{* * *}$ & $(0.002)$ \\
Pre displacement Plant size & $-0.025^{* * *}$ & $(0.003)$ & $-0.030^{* * *}$ & $(0.005)$ & $-0,023^{* * *}$ & $(0.003)$ \\
Pre dpl. size of the labour market & $-0.002^{* *}$ & $(0.001)$ & $-0.004^{* *}$ & $(0.002)$ & $-0,002$ & $(0.001)$ \\
Regional rate of unemployment & $0.008^{* * *}$ & $(0.002)$ & $0.016^{* * *}$ & $(0.004)$ & $0,005^{* *}$ & $(0.002)$ \\
Displaced at $t-7$ & $0.052^{* * *}$ & $(0.004)$ & $0.062^{* * *}$ & $(0.009)$ & $0,046^{* * *}$ & $(0.005)$ \\
\hline No. of observations & \multicolumn{2}{c}{112263} & & 35182 & & 77081 \\
R-squared & \multicolumn{2}{c}{0.0467} & \multicolumn{2}{c}{0.0665} & & 0.0221 \\
\hline
\end{tabular}

The dependent variable is the probability of being outside labor force. Table reports the marginal effects of probit regression using data for 1998. Displacements happened between May 1991 and May 1992. The sample consists of male workers, who were 25-55 year old and full time employed in manufacturing plants with at least five employees in 1991, and who were in the labour force and not displaced from their jobs in the previous three years. The specification contains pre-displacement (year 1991) industry dummies. Huber-White robust standard errors allowing for clustering of errors by individuals are in parentheses. The model is estimated separately for the age groups. Young workers are $25-44$ years-old at the time of displacement and old workers are 45-55 years-old at the time of displacement. 


\begin{tabular}{|c|c|c|c|c|c|c|c|c|}
\hline \multirow{3}{*}{$\begin{array}{l}\text { Sample: } \\
\text { Age }\end{array}$} & \multicolumn{4}{|c|}{ All workers } & \multicolumn{4}{|c|}{ Workers who are in the labor force } \\
\hline & \multicolumn{2}{|c|}{ OLS } & \multicolumn{2}{|c|}{ FE } & \multicolumn{2}{|c|}{ OLS } & \multicolumn{2}{|c|}{$\mathrm{FE}$} \\
\hline & $0.119 * * *$ & $(0.004)$ & $0.074 * * *$ & $(0.003)$ & $0.082 * * *$ & $(0.003)$ & $0.099 * * *$ & $(0.002)$ \\
\hline Age squared & $-0.001 * * *$ & $(0.000)$ & $-0.002 * * *$ & $(0.000)$ & $-0.001 * * *$ & $(0.000)$ & $-0.001^{* * *}$ & $(0.000)$ \\
\hline Years of schooling & $0.053 * * *$ & $(0.002)$ & & & $0.046^{* * *}$ & $(0.001)$ & & \\
\hline Pre displacement tenure & $0.049 * * *$ & $(0.001)$ & & & $0.039 * * *$ & $(0.001)$ & & \\
\hline Pre displacement marital status & $0.308^{* * *}$ & $(0.010)$ & & & $0.262 * * *$ & $(0.008)$ & & \\
\hline Pre displacement Plant size & $0.027 * * *$ & $(0.001)$ & & & $0.018 * * *$ & $(0.001)$ & & \\
\hline Pre dpl. size of the labor market & $0.008 * * *$ & $(0.001)$ & & & $0.007 * * *$ & $(0.001)$ & & \\
\hline Regional rate of unemployment & $-0.186 * * *$ & $(0.007)$ & $-0.219 * * * *$ & $(0.005)$ & $-0.191 * * *$ & $(0.006)$ & $-0.212^{* * *}$ & $(0.004)$ \\
\hline Displaced at $t+3$ & $-0.188^{* * *}$ & $(0.027)$ & & & $-0.198^{* * *}$ & $(0.026)$ & & \\
\hline Displaced at $t+2$ & $-0.287 * * *$ & $(0.029)$ & $-0.101^{* * *}$ & $(0.038)$ & $-0.297 * * *$ & $(0.029)$ & $-0.100 * * *$ & (0.029) \\
\hline Displaced at $t+1$ & $-0.273 * * *$ & $(0.026)$ & $-0.087 * *$ & $(0.038)$ & $-0.282 * * *$ & $(0.026)$ & $-0.084^{* * *}$ & (0.029) \\
\hline Displaced at $t$ & $-0.391 * * *$ & $(0.016)$ & $-0.202 * * * *$ & $(0.038)$ & $-0.399 * * *$ & $(0.016)$ & $-0.199 * * *$ & (0.029) \\
\hline Displaced at $t-1$ & $-2.691 * * *$ & $(0.059)$ & $-2.500 * * *$ & $(0.038)$ & $-2.208 * * *$ & $(0.056)$ & $-2.001^{* * *}$ & $(0.030)$ \\
\hline Displaced at $t-2$ & $-1.808 * * *$ & $(0.056)$ & $-1.638 * * *$ & (0.039) & $-1.417 * * *$ & $(0.051)$ & $-1.242 * * *$ & $(0.030)$ \\
\hline Displaced at $t-3$ & $-1.417 * * *$ & $(0.053)$ & $-1.260 * * *$ & $(0.039)$ & $-1.007 * * *$ & $(0.046)$ & $-0.851^{* * *}$ & $(0.030)$ \\
\hline Displaced at $t-4$ & $-1.060 * * *$ & $(0.051)$ & $-0.915^{* * *}$ & (0.039) & $-0.702 * * *$ & $(0.042)$ & $-0.557 * * *$ & $(0.030)$ \\
\hline Displaced at $t-5$ & $-0.962 * * *$ & $(0.052)$ & $-0.831^{* * *}$ & $(0.039)$ & $-0.608 * * *$ & $(0.040)$ & $-0.481^{* * *}$ & $(0.030)$ \\
\hline Displaced at $t-6$ & $-0.624 * * *$ & $(0.049)$ & $-0.497 * * *$ & $(0.039)$ & $-0.321 * * *$ & $(0.034)$ & $-0.204^{* * *}$ & $(0.030)$ \\
\hline Displaced at $t-7$ & $-0.556 * * *$ & $(0.050)$ & $-0.422 * * *$ & $(0.039)$ & $-0.140 * * *$ & $(0.030)$ & -0.021 & $(0.030)$ \\
\hline No. of observations & \multirow{2}{*}{\multicolumn{2}{|c|}{$\begin{array}{c}1238891 \\
0.0548\end{array}$}} & \multirow{2}{*}{\multicolumn{2}{|c|}{$\begin{array}{c}1238891 \\
0.0348\end{array}$}} & \multirow{2}{*}{\multicolumn{2}{|c|}{$\begin{array}{c}1210385 \\
0.0483\end{array}$}} & \multirow{2}{*}{\multicolumn{2}{|c|}{$\begin{array}{c}1210385 \\
0.0191\end{array}$}} \\
\hline R-squared & & & & & & & & \\
\hline
\end{tabular}

The dependent variable is months of employment. Displacements happened between May 1991 and May 1992. $t$ is the year of the observation. The sample covers the years 1988 to 1998, and consists of male workers, who were 25-55 year old and full time employed in manufacturing plants with at least five employees in 1991, and who were in the labor force and not displaced from their jobs in the previous three years. The specification without individual fixed effects contains region dummies and pre-displacement industry dummies. Both specifications contain time dummies. Huber-White robust standard errors allowing for clustering of errors by individuals are in parentheses. 


\begin{tabular}{|c|c|c|c|c|c|c|c|c|}
\hline \multirow{3}{*}{$\begin{array}{l}\text { Sample: } \\
\text { Age }\end{array}$} & \multicolumn{4}{|c|}{ All workers } & \multicolumn{4}{|c|}{ Employed workers } \\
\hline & \multicolumn{2}{|c|}{ OLS } & \multicolumn{2}{|c|}{ FE } & \multicolumn{2}{|c|}{ OLS } & \multicolumn{2}{|c|}{$\mathrm{FE}$} \\
\hline & $0.052 * * *$ & $(0.001)$ & 0.070 & $(0.001)$ & $0.040 * * *$ & $(0.001)$ & $0.057 * * *$ & $(0.000)$ \\
\hline Age squared & $-0.001 * * *$ & $(0.000)$ & -0.001 & $(0.000)$ & $0.000 * * *$ & $(0.000)$ & $-0.001 * * *$ & $(0.000)$ \\
\hline Years of schooling & $0.066^{* * *}$ & $(0.000)$ & & & $0.061^{* * *}$ & $(0.000)$ & & \\
\hline Pre displacement tenure & $0.003 * * *$ & $(0.000)$ & & & $0.001 * * *$ & $(0.000)$ & & \\
\hline Pre displacement marital status & $0.104 * * *$ & $(0.002)$ & & & $0.081 * * *$ & $(0.002)$ & & \\
\hline Pre displacement Plant size & $0.006 * * *$ & $(0.000)$ & & & $0.005^{* * *}$ & $(0.000)$ & & \\
\hline Pre dpl. size of the labor market & $0.003 * * *$ & $(0.000)$ & & & $0.003 * * *$ & $(0.000)$ & & \\
\hline Regional rate of unemployment & $-0.018 * * *$ & $(0.001)$ & $-0.016 * * *$ & $(0.001)$ & $-0.013 * * *$ & $(0.001)$ & $-0.010 * * *$ & $(0.001)$ \\
\hline Displaced at $t+3$ & $-0.013^{* * *}$ & $(0.004)$ & & & $-0.007 *$ & $(0.004)$ & & \\
\hline Displaced at $t+2$ & $-0.022 * * *$ & $(0.004)$ & -0.010 & $(0.006)$ & $-0.013 * * *$ & $(0.004)$ & $-0.007^{*}$ & $(0.004)$ \\
\hline Displaced at $t+1$ & $-0.017 * * *$ & $(0.004)$ & -0.006 & $(0.006)$ & $-0.009 * *$ & (0.004) & -0.004 & (0.004) \\
\hline Displaced at $t$ & $-0.043^{* * *}$ & $(0.005)$ & $-0.032 * * *$ & $(0.006)$ & $-0.043^{* * *}$ & $(0.005)$ & $-0.034 * * *$ & (0.004) \\
\hline Displaced at $t-1$ & $-0.088 * * *$ & $(0.007)$ & $-0.080 * * *$ & $(0.006)$ & $0.021 * * *$ & (0.004) & -0.001 & (0.004) \\
\hline Displaced at $t-2$ & $-0.111^{* * *}$ & $(0.008)$ & $-0.108 * * *$ & $(0.006)$ & $-0.023 * * *$ & $(0.005)$ & $-0.034 * * *$ & (0.004) \\
\hline Displaced at $t-3$ & $-0.097 * * *$ & $(0.008)$ & $-0.098 * * *$ & $(0.006)$ & $-0.030 * * *$ & $(0.005)$ & $-0.036 * * *$ & (0.004) \\
\hline Displaced at $t-4$ & $-0.090 * * *$ & $(0.008)$ & $-0.096 * * *$ & $(0.006)$ & $-0.038 * * *$ & $(0.005)$ & $-0.041 * * *$ & (0.004) \\
\hline Displaced at $t-5$ & $-0.060 * * *$ & $(0.008)$ & $-0.069 * * *$ & $(0.006)$ & $-0.015^{* * *}$ & $(0.005)$ & $-0.020 * * *$ & (0.004) \\
\hline Displaced at $t-6$ & $-0.048^{* * *}$ & $(0.008)$ & $-0.058 * * *$ & $(0.006)$ & $-0.015 * * *$ & $(0.005)$ & $-0.019 * * *$ & (0.004) \\
\hline Displaced at $t-7$ & $-0.037 * * *$ & $(0.009)$ & $-0.043 * * *$ & $(0.006)$ & $-0.001 * * *$ & $(0.005)$ & -0.001 & $(0.004)$ \\
\hline $\begin{array}{l}\text { No. of observations } \\
\text { R-squared }\end{array}$ & \multicolumn{2}{|c|}{1238891} & 1238891 & & 1179728 & & 1179728 & \\
\hline
\end{tabular}

The dependent variable is log annual earnings. Displacements happened between May 1991 and May 1992. $t$ is the year of the observation. The sample covers the years 1988 to 1998, and consists of male workers, who were 25-55 year old and full time employed in manufacturing plants with at least five employees in 1991, and who were in the labor force and not displaced from their jobs in the previous three years. The specification without individual fixed effects contains region dummies and pre-displacement industry dummies. Both specifications contain time dummies. Huber-White robust standard errors allowing for clustering of errors by individuals are in parentheses. 


\begin{tabular}{|c|c|c|c|c|c|c|c|c|c|c|c|}
\hline \multirow{2}{*}{$\frac{\text { OLS }}{\text { Year }-3}$} & Displaced & \multicolumn{2}{|c|}{ Displaced*Employed } & \multicolumn{2}{|c|}{ Unemployed } & \multicolumn{2}{|c|}{ Displaced* Unempl. } & \multicolumn{2}{|c|}{ Out of labor force } & \multicolumn{2}{|c|}{$\begin{array}{l}\text { Displaced* Out of } \\
\text { labor force }\end{array}$} \\
\hline & $-0.014 * * * \quad(0.004)$ & & & & & & & & & & \\
\hline Year -2 & $-0.024 * * * \quad(0.004)$ & & & & & & & & & & \\
\hline Year -1 & $-0.018 * * * \quad(0.004)$ & & & & & & & & & & \\
\hline Year 0 & $-0.044 * * * \quad(0.005)$ & & & & & & & & & & \\
\hline Year 1 & & $0.017 * * *$ & $(0.004)$ & $-0.367 * * *$ & $(0.011)$ & $0.072 * * *$ & $(0.017)$ & $-1.305^{* * *}$ & $(0.044)$ & $0.298 * * *$ & $(0.081)$ \\
\hline Year 2 & & $-0.026 * * *$ & $(0.005)$ & $-0.384^{* * *}$ & $(0.008)$ & 0.013 & $(0.018)$ & $-1.530 * * *$ & $(0.039)$ & 0.154 & $(0.094)$ \\
\hline Year 3 & & $-0.033^{* * *}$ & $(0.005)$ & $-0.463^{* * *}$ & $(0.010)$ & $0.084 * * *$ & $(0.022)$ & $-1.439 * * *$ & $(0.034)$ & $0.210^{* *}$ & $(0.085)$ \\
\hline Year 4 & & $-0.041 * * *$ & $(0.005)$ & $-0.538 * * *$ & $(0.013)$ & 0.029 & $(0.030)$ & $-1.404^{* * *}$ & $(0.031)$ & $0.201^{* *}$ & $(0.085)$ \\
\hline Year 5 & & $-0.018 * * *$ & $(0.005)$ & $-0.550 * * *$ & $(0.015)$ & 0.036 & $(0.041)$ & $-1.125^{* * *}$ & $(0.024)$ & $0.150 * *$ & $(0.072)$ \\
\hline Year 6 & & $-0.019 * * *$ & $(0.005)$ & $-0.656^{* * *}$ & $(0.018)$ & -0.020 & $(0.059)$ & $-1.265^{* * *}$ & $(0.023)$ & $0.226 * * *$ & $(0.071)$ \\
\hline Year 7 & & -0.004 & $(0.005)$ & $-0.649 * * *$ & $(0.020)$ & -0.080 & $(0.077)$ & $-1.282 * * *$ & $(0.021)$ & $0.232 * * *$ & $(0.067)$ \\
\hline R-squared & 0.3110 & & & & & & & & & & \\
\hline FE & Displaced & Displaced* & Employed & \multicolumn{2}{|c|}{ Unemployed } & \multicolumn{2}{|c|}{ Displaced*Unempl. } & \multicolumn{2}{|c|}{ Out of labor force } & \multicolumn{2}{|c|}{$\begin{array}{c}\text { Displaced* Out of } \\
\text { labor force }\end{array}$} \\
\hline Year -2 & $(0.006)$ & & & & & & & & & & \\
\hline Year -1 & $(0.006)$ & & & & & & & & & & \\
\hline Year 0 & $-0.032 * * * \quad(0.006)$ & & & & & & & & & & \\
\hline Year 1 & & $-0.013^{* *}$ & $(0.006)$ & $-0.194^{* * *}$ & $(0.008)$ & 0.015 & $(0.013)$ & $-0.990 * * *$ & $(0.009)$ & $0.235^{* * *}$ & $(0.019)$ \\
\hline Year 2 & & $-0.045^{* * *}$ & $(0.006)$ & $-0.209 * * *$ & $(0.006)$ & -0.017 & $(0.013)$ & $-1.254^{* * *}$ & $(0.007)$ & $0.095^{* * *}$ & $(0.018)$ \\
\hline Year 3 & & $-0.047 * * *$ & $(0.006)$ & $-0.268 * * *$ & $(0.006)$ & $0.025^{*}$ & $(0.015)$ & $-1.205^{* * *}$ & $(0.007)$ & $0.159 * * *$ & $(0.018)$ \\
\hline Year 4 & & $-0.054 * * *$ & $(0.006)$ & $-0.343 * * *$ & $(0.007)$ & 0.006 & $(0.018)$ & $-1.192 * * *$ & $(0.006)$ & $0.163 * * *$ & $(0.018)$ \\
\hline Year 5 & & $-0.033 * * *$ & $(0.006)$ & $-0.387 * * *$ & $(0.007)$ & 0.009 & $(0.019)$ & $-0.976 * * *$ & $(0.005)$ & $0.142^{* * *}$ & $(0.016)$ \\
\hline Year 6 & & $-0.033 * * *$ & $(0.006)$ & $-0.492 * * *$ & $(0.008)$ & -0.031 & $(0.023)$ & $-1.106^{* * *}$ & $(0.005)$ & $0.231^{* * *}$ & $(0.016)$ \\
\hline Year 7 & & $-0.014 * * *$ & $(0.006)$ & $-0.523 * * *$ & $(0.008)$ & $-0.083 * * *$ & $(0.028)$ & $-1.155^{* * *}$ & $(0.005)$ & $0.238 * * *$ & $(0.015)$ \\
\hline $\begin{array}{l}\text { R-squared } \\
\text { No. of observations }\end{array}$ & $\begin{array}{c}0.1949 \\
1238891\end{array}$ & & & & & & & & & & \\
\hline
\end{tabular}

The dependent variable is log annual earnings. Displacements happened between May 1991 (year -0) and May 1992 (year 1). The sample covers the years 1988 to 1998 , and consists of male workers, who were 25-55 year old and full time employed in manufacturing plants with at least five employees in 1991, and who were in the labor force and not displaced from their jobs in the previous three years. The following control variables are included, but not reported: Age, age squared, years of schooling, tenure when displaced, marital status when displaced, plant size when displaced, size of the regional labor market when displaced, regional rate of unemployment, region dummies, pre-displacement industry dummies, and time dummies. Huber-White robust standard errors allowing for clustering of errors by individuals are in parentheses. 


\begin{tabular}{|c|c|c|c|c|c|}
\hline OLS & Same firm/plant & Same industry & Other manufacturing & Privat service & Public service \\
\hline Displaced at $t-1$ & $\begin{array}{l}0.028 * * * \\
(0.008)\end{array}$ & $\begin{array}{l}-0.004 \\
(0.006)\end{array}$ & $\begin{array}{l}-0.027 \\
(0.017)\end{array}$ & $\begin{array}{c}0.077 * * * \\
(0.008)\end{array}$ & $\begin{array}{c}-0.189 * * * \\
(0.038)\end{array}$ \\
\hline Displaced at $t-2$ & $\begin{array}{c}-0.017 \\
(0.011)\end{array}$ & $\begin{array}{c}-0.037 * * * \\
(0.007)\end{array}$ & $\begin{array}{c}-0.097 * * * \\
(0.032)\end{array}$ & $\begin{array}{c}0.043 * * * \\
(0.008)\end{array}$ & $\begin{array}{c}-0.286 * * * \\
(0.028)\end{array}$ \\
\hline Displaced at $t-3$ & $\begin{array}{l}-0.014 \\
(0.014)\end{array}$ & $\begin{array}{c}-0.033^{* * *} \\
(0.007)\end{array}$ & $\begin{array}{c}-0.053 * * * \\
(0.016)\end{array}$ & $\begin{array}{c}0.006 \\
(0.010)\end{array}$ & $\begin{array}{c}-0.280^{* * *} \\
(0.022)\end{array}$ \\
\hline Displaced at $t-4$ & $\begin{array}{l}-0.002 \\
(0.010)\end{array}$ & $\begin{array}{c}-0.032 * * * \\
(0.007)\end{array}$ & $\begin{array}{c}-0.089 * * * \\
(0.022)\end{array}$ & $\begin{array}{l}-0.014 \\
(0.011)\end{array}$ & $\begin{array}{c}-0.319 * * * \\
(0.032)\end{array}$ \\
\hline Displaced at $t-5$ & $\begin{array}{c}0.040 * * * \\
(0.009)\end{array}$ & $\begin{array}{c}-0.023^{* * *} \\
(0.008)\end{array}$ & $\begin{array}{c}-0.065^{* * *} \\
(0.017)\end{array}$ & $\begin{array}{l}0.017^{*} \\
(0.010)\end{array}$ & $\begin{array}{c}-0.264 * * * \\
(0.028)\end{array}$ \\
\hline Displaced at $t-6$ & $\begin{array}{c}0.007 \\
(0.010)\end{array}$ & $\begin{array}{l}-0.015^{*} \\
(0.008)\end{array}$ & $\begin{array}{c}-0.062 * * * \\
(0.017)\end{array}$ & $\begin{array}{c}0.015 \\
(0.011)\end{array}$ & $\begin{array}{c}-0.235^{* * * *} \\
(0.028)\end{array}$ \\
\hline Displaced at $t-7$ & $\begin{array}{l}0.021^{* *} \\
(0.010)\end{array}$ & $\begin{array}{c}0.003 \\
(0.008) \\
\end{array}$ & $\begin{array}{c}-0.057 * * * \\
(0.018) \\
\end{array}$ & $\begin{array}{c}0.028 * * * \\
(0.011)\end{array}$ & $\begin{array}{c}-0.234^{* * *} \\
(0.033) \\
\end{array}$ \\
\hline R_sq. & 0.2506 & & & & \\
\hline FE & Same firm/plant & Same industry & Other manufacturing & Privat service & Public service \\
\hline Displaced at $t-1$ & $\begin{array}{l}-0.009 \\
(0.007)\end{array}$ & $\begin{array}{c}0.015^{* *} \\
(0.006)\end{array}$ & $\begin{array}{l}-0.007 \\
(0.014)\end{array}$ & $\begin{array}{l}-0.004 \\
(0.007)\end{array}$ & $\begin{array}{c}-0.079 * * * \\
(0.023)\end{array}$ \\
\hline Displaced at $t-2$ & $\begin{array}{c}-0.038 * * * \\
(0.008)\end{array}$ & $\begin{array}{c}-0.025^{* * *} \\
(0.006)\end{array}$ & $\begin{array}{c}-0.047 * * * \\
(0.014)\end{array}$ & $\begin{array}{c}-0.022 * * * \\
(0.007)\end{array}$ & $\begin{array}{c}-0.170^{* * *} \\
(0.018)\end{array}$ \\
\hline Displaced at $t-3$ & $\begin{array}{c}-0.032 * * * \\
(0.008)\end{array}$ & $\begin{array}{c}-0.025^{* * *} \\
(0.006)\end{array}$ & $\begin{array}{l}-0.019 \\
(0.012)\end{array}$ & $\begin{array}{c}-0.038 * * * \\
(0.007)\end{array}$ & $\begin{array}{c}-0.174^{* * *} \\
(0.017)\end{array}$ \\
\hline Displaced at $t-4$ & $\begin{array}{c}-0.024 * * * \\
(0.008)\end{array}$ & $\begin{array}{c}-0.032 * * * \\
(0.006)\end{array}$ & $\begin{array}{c}-0.050 * * * \\
(0.012)\end{array}$ & $\begin{array}{c}-0.042 * * * \\
(0.007)\end{array}$ & $\begin{array}{c}-0.187 * * * \\
(0.016)\end{array}$ \\
\hline Displaced at $t-5$ & $\begin{array}{l}0.020^{* *} \\
(0.008)\end{array}$ & $\begin{array}{c}-0.021^{* * *} \\
(0.006)\end{array}$ & $\begin{array}{c}-0.029 * * * \\
(0.011)\end{array}$ & $\begin{array}{c}-0.021^{* * *} \\
(0.007)\end{array}$ & $\begin{array}{c}-0.145^{* * *} \\
(0.016)\end{array}$ \\
\hline Displaced at $t-6$ & $\begin{array}{l}-0.008 \\
(0.008)\end{array}$ & $\begin{array}{c}-0.015^{* * *} \\
(0.006)\end{array}$ & $\begin{array}{l}-0.013 \\
(0.011)\end{array}$ & $\begin{array}{c}-0.016 * * \\
(0.006)\end{array}$ & $\begin{array}{c}-0.132 * * * \\
(0.016)\end{array}$ \\
\hline Displaced at $t-7$ & $\begin{array}{c}0.010 \\
(0.008)\end{array}$ & $\begin{array}{c}0.000 \\
(0.006)\end{array}$ & $\begin{array}{c}0.000 \\
(0.011)\end{array}$ & $\begin{array}{c}0.009 \\
(0.006)\end{array}$ & $\begin{array}{c}-0.135^{* * *} \\
(0.016)\end{array}$ \\
\hline $\begin{array}{l}\text { R_sq. } \\
\text { Obs }\end{array}$ & $\begin{array}{c}0.0577 \\
1179728 \\
\end{array}$ & & & & \\
\hline
\end{tabular}

The dependent variable is log annual earnings. Displacements happened between May 1991 and May 1992. $t$ is the year of the observation. The sample covers the years 1988 to 1998, and consists of employed male workers, who were 25-55 year old and full time employed in manufacturing plants with at least five employees in 1991, and who were in the labor force and not displaced from their jobs in the previous three years. The following control variables are included, but not reported: Age, age squared, years of schooling, tenure when displaced, marital status when displaced, plant size when displaced, size of the regional labor market when displaced, regional rate of unemployment, region dummies, predisplacement industry dummies, and time dummies. Huber-White robust standard errors allowing for clustering of errors by individuals are in parentheses. 


\begin{tabular}{|c|c|c|c|c|c|c|c|c|c|c|c|c|}
\hline \multirow{3}{*}{$\begin{array}{l}\text { Outcome: } \\
\text { Employment } \\
\text { Displaced at } t+3\end{array}$} & \multicolumn{6}{|c|}{ OLS } & \multicolumn{6}{|c|}{ FE } \\
\hline & \multicolumn{2}{|c|}{ Exit-layoffs } & \multicolumn{2}{|c|}{ Early-leavers } & \multicolumn{2}{|c|}{ Downsizing separators } & \multicolumn{2}{|c|}{ Exit-layoffs } & \multicolumn{2}{|c|}{ Early-leavers } & \multicolumn{2}{|c|}{ Downsizing separators } \\
\hline & $-0.115^{* *}$ & $(0.006)$ & $-0.261^{* * *}$ & $(0.006)$ & $-0.189 * * *$ & $(0.006)$ & & & & & & \\
\hline Displaced at $t+2$ & 0.024 & $(0.006)$ & $-0.410 * * *$ & $(0.006)$ & $-0.427 * * *$ & $(0.007)$ & $0.140 * *$ & $(0.068)$ & $-0.157^{* *}$ & $(0.072)$ & $-0.236 * * *$ & $(0.058)$ \\
\hline Displaced at $t+1$ & 0.048 & $(0.007)$ & $-0.318 * * *$ & $(0.007)$ & $-0.471^{* * *}$ & $(0.006)$ & $0.164 * *$ & $(0.068)$ & -0.056 & $(0.072)$ & $-0.286 * * *$ & $(0.058)$ \\
\hline Displaced at $t$ & $-0.504^{* * *}$ & $(0.009)$ & $-0.364 * * *$ & $(0.008)$ & $-0.324 * * *$ & $(0.007)$ & $-0.386 * * *$ & $(0.068)$ & -0.101 & $(0.072)$ & $-0.137 * *$ & $(0.058)$ \\
\hline Displaced at $t-1$ & $-2.625^{* * *}$ & $(0.007)$ & $-1.918 * * *$ & $(0.008)$ & $-3.236 * * *$ & $(0.007)$ & $-2.507 * * *$ & $(0.068)$ & $-1.657 * * *$ & $(0.072)$ & $-3.041 * * *$ & $(0.058)$ \\
\hline Displaced at $t-2$ & $-1.730 * * *$ & $(0.010)$ & $-1.650 * * *$ & $(0.009)$ & $-1.965 * * *$ & $(0.007)$ & $-1.636 * * *$ & $(0.069)$ & $-1.398 * * *$ & $(0.072)$ & $-1.794 * * *$ & $(0.058)$ \\
\hline Displaced at $t-3$ & $-1.431^{* * *}$ & $(0.008)$ & $-1.280 * * *$ & $(0.011)$ & $-1.492 * * *$ & $(0.008)$ & $-1.351^{* * *}$ & $(0.069)$ & $-1.016^{* * *}$ & $(0.072)$ & $-1.352 * * *$ & $(0.059)$ \\
\hline Displaced at $t-4$ & $-1.123^{* * *}$ & $(0.010)$ & $-0.938 * * *$ & $(0.010)$ & $-1.092 * * *$ & $(0.008)$ & $-1.067 * * *$ & $(0.069)$ & $-0.695^{* * *}$ & $(0.072)$ & $-0.951 * * *$ & $(0.059)$ \\
\hline Displaced at $t-5$ & $-0.878 * * *$ & $(0.007)$ & $-0.716^{* * *}$ & $(0.009)$ & $-1.179 * * *$ & (0.009) & $-0.839 * * *$ & $(0.069)$ & $-0.481^{* * *}$ & $(0.073)$ & $-1.054 * * *$ & $(0.059)$ \\
\hline Displaced at $t-6$ & $-0.548 * * *$ & $(0.009)$ & $-0.534 * * *$ & $(0.009)$ & $-0.733 * * *$ & $(0.009)$ & $-0.509 * * *$ & $(0.070)$ & $-0.297 * * *$ & $(0.073)$ & $-0.617 * * *$ & $(0.059)$ \\
\hline Displaced at $t-7$ & $-0.423^{* * *}$ & $(0.009)$ & $-0.768 * * *$ & $(0.009)$ & $-0.508 * * *$ & $(0.009)$ & $-0.378 * * *$ & $(0.070)$ & $-0.541 * * *$ & $(0.073)$ & $-0.374 * * *$ & $(0.059)$ \\
\hline $\begin{array}{l}\text { No. of obs. } \\
\text { R-squared }\end{array}$ & $\begin{array}{c}1238891 \\
0.0552 \\
\end{array}$ & & & & & & $\begin{array}{c}1238891 \\
0.0352\end{array}$ & & & & & \\
\hline $\begin{array}{l}\text { Outcome: } \\
\text { Earnings }\end{array}$ & Exit-l & roffs & $\begin{array}{r}\mathrm{O} \\
\text { Early- }\end{array}$ & avers & Downsizin & separators & Exit- & & Early- & ers & Downsizin & parators \\
\hline Displaced at $t+3$ & 005 & $(0.00$ & $-0.035 * * *$ & $(0.007)$ & -0.003 & $(0.006)$ & & & & & & \\
\hline Displaced at $t+2$ & $-0.012 * * *$ & $(0.006)$ & $-0.033^{* * *}$ & $(0.007)$ & $-0.022 * * *$ & $(0.007)$ & -0.010 & $(0.011)$ & 0.002 & $(0.012)$ & $-0.018^{*}$ & $(0.009)$ \\
\hline Displaced at $t+1$ & $-0.017 * *$ & $(0.007)$ & $-0.018 * * *$ & $(0.007)$ & $-0.014^{* *}$ & $(0.006)$ & -0.014 & $(0.011)$ & 0.017 & $(0.012)$ & $-0.016^{*}$ & $(0.009)$ \\
\hline Displaced at $t$ & $-0.082 * * *$ & $(0.009)$ & $-0.030 * * *$ & $(0.008)$ & $-0.022 * * *$ & $(0.007)$ & $-0.080 * * *$ & $(0.011)$ & 0.005 & $(0.012)$ & $-0.021^{* *}$ & $(0.009)$ \\
\hline Displaced at $t-1$ & $-0.101^{* * *}$ & $(0.013)$ & $-0.060 * * *$ & $(0.012)$ & $-0.095^{* * *}$ & $(0.011)$ & $-0.101^{* * *}$ & $(0.011)$ & $-0.029 * *$ & $(0.012)$ & $-0.097 * * *$ & $(0.010)$ \\
\hline Displaced at $t-2$ & $-0.158 * * *$ & $(0.016)$ & $-0.080 * * *$ & $(0.013)$ & $-0.096 * * *$ & $(0.014)$ & $-0.164 * * *$ & $(0.011)$ & $-0.049 * * *$ & $(0.012)$ & $-0.106 * * *$ & $(0.010)$ \\
\hline Displaced at $t-3$ & $-0.143^{* * *}$ & $(0.015)$ & $-0.091 * * *$ & $(0.015)$ & $-0.067 * * *$ & $(0.012)$ & $-0.155^{* * *}$ & $(0.011)$ & $-0.057 * * *$ & $(0.012)$ & $-0.084 * * *$ & $(0.010)$ \\
\hline Displaced at $t-4$ & $-0.119 * * *$ & $(0.015)$ & $-0.085 * * *$ & $(0.015)$ & $-0.072 * * *$ & $(0.013)$ & $-0.138 * * *$ & $(0.011)$ & $-0.056 * * *$ & $(0.012)$ & $-0.090 * * *$ & $(0.010)$ \\
\hline Displaced at $t-5$ & $-0.096 * * *$ & $(0.015)$ & $-0.023^{*}$ & $(0.015)$ & $-0.058 * * *$ & $(0.013)$ & $-0.120 * * *$ & $(0.011)$ & 0.001 & $(0.012)$ & $-0.079 * * *$ & $(0.010)$ \\
\hline Displaced at $t-6$ & $-0.088 * * *$ & $(0.015)$ & $-0.029 *$ & $(0.014)$ & $-0.031^{* *}$ & $(0.013)$ & $-0.111^{* * *}$ & $(0.011)$ & -0.004 & $(0.012)$ & $-0.055 * * *$ & $(0.010)$ \\
\hline Displaced at $t-7$ & $-0.083 * * *$ & $(0.017)$ & 0.003 & $(0.015)$ & $-0.028 * *$ & $(0.014)$ & $-0.101^{* * *}$ & $(0.011)$ & $0.025 * *$ & $(0.012)$ & $-0.045 * * *$ & $(0.010)$ \\
\hline $\begin{array}{l}\text { No. of obs. } \\
\text { R-squared }\end{array}$ & $\begin{array}{c}1238891 \\
0.1609\end{array}$ & & & & & & $\begin{array}{c}1238891 \\
0.0188\end{array}$ & & & & & \\
\hline
\end{tabular}

The dependent variable is months of employment in the upper panel, and log annual earnings in the lower panel. Displacements happened between May 1991 and May $1992 . t$ is the year of the observation. The sample covers the years 1988 to 1998, and consists of employed male workers, who were 25-55 year old and full time employed in manufacturing plants with at least five employees in 1991, and who were in the labor force and not displaced from their jobs in the previous three years. The following control variables are included, but not reported: Age, age squared, years of schooling, tenure when displaced, marital status when displaced, plant size when displaced, size of the regional labor market when displaced, regional rate of unemployment, region dummies, pre-displacement industry dummies, and time dummies. Huber-White robust standard errors allowing for clustering of errors by individuals are in parentheses. 